\title{
EVALUATION OF RESIDUE DRUM STORAGE SAFETY RISKS
}

\author{
William V. Conner
}

JUNE 17, 1994

SUBJECT DESCRIPTORS

Safety

Drums

Residue

Plutonium

Prepared Under Contract DE-AC04-90DE62349

for the

Albuquerque Operations Office

U. S. Department of Energy

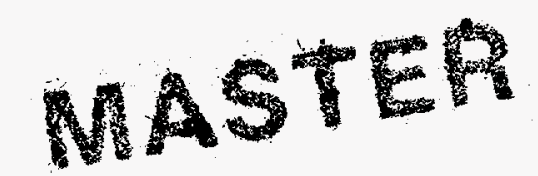




\section{DISCLAIMER}

This report was prepared as an account of work sponsored by an agency of the United States Government. Niether the United States government nor any agency thereof, nor any of their employees, makes any warranty, expressed or implied, or assumes any legal liability or responsibility for the accuracy, completeness, or usefulness of any information, appraratus, product, or process disclosed, or represents that its use would not infringe privately owned rights. Reference herein to any specific commercial product, process, or service by trade name, trademark, manufacturer, or otherwise, does not necessarily constitute or imply its endorsement, recommendation, or favoring by the United States Government or any agency thereof. The view and opinions of authors expressed herein do not necessarily state or reflect those of the United States Government or any agency thereof.

This report has been reporduced directly from the best available copy.

Available to DOE and DOE contractors from the Office of Scientific and Technicl Information, P. O. Box 62, Oak Ridge, TN 37831; prices available from (615) 576-8401, FTS 626-8401.

Available to the public from the National Technical Information Service, U. S. Department of Commerce, 5285 Port Toyal Rd., Springfield, VA 22161.

\section{ACKNOWLEDGEMENT}

The author wishes to acknowledge M. Ojeda and G. G. Griesinger, SNM Management, for preparation of the residue drum database used for this study. The author would also like to acknowledge the assistance of D. L. Cox, Residue Operations Technical Support, in obtaining the packaging configuration information used in this report. 


\section{TABLE OF CONTENTS}

DISCLAMMER $\ldots \ldots \ldots \ldots \ldots \ldots \ldots \ldots \ldots \ldots \ldots \ldots \ldots \ldots \ldots \ldots \ldots \ldots \ldots$

ACKNOWLEDGEMENT $\ldots \ldots \ldots \ldots \ldots \ldots \ldots \ldots \ldots \ldots \ldots \ldots \ldots$

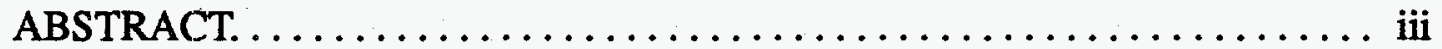

SUMMARY $\ldots \ldots \ldots \ldots \ldots \ldots \ldots \ldots \ldots \ldots \ldots \ldots \ldots \ldots \ldots \ldots \ldots \ldots \ldots \ldots$ iii

INTRODUCTION $\ldots \ldots \ldots \ldots \ldots \ldots \ldots \ldots \ldots \ldots \ldots \ldots \ldots \ldots \ldots \ldots$

DATABASE DEVELOPMENT. . . . . . . . . . . . . . . . . . . . . .

RESIDUE PACKAGING. $\ldots \ldots \ldots \ldots \ldots \ldots \ldots \ldots \ldots \ldots \ldots \ldots \ldots \ldots \ldots \ldots \ldots$

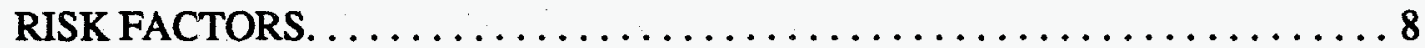

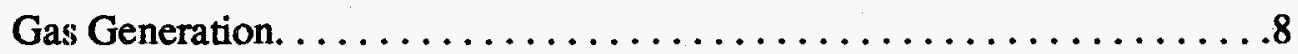

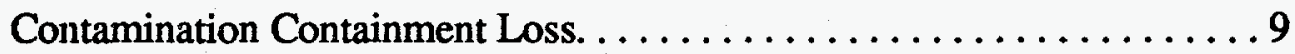

Drum anỏ Residue Packaging Corrosion. ................ 9

Reactive Metals and Compounds.................... 10

RESIDUE IDC RISK RANKINGS. . . . . . . . . . . . . . . . . 11

DISCUSSION. ..................................... 17

Gas Generation. .................................. 17

Contamination Containment Loss. . . . . . . . . . . . . . . . . 29

Drum and Residue Packaging Corrosion. . . . . . . . . . . . . . 31

Reactive Metals and Compounds..................... 31

CONCLUSIONS AND RECOMMENDATIONS. ............... 33

REFERENCES. ................................... 33 


\section{DISCLAIMER}

Portions of this document may be illegible in electronic image products. Images are produced from the best available original document. 


\section{ABSTRACT}

A study was conducted to determine if any potential safety problems exist in the residue drum backlog at the Rocky Flats Plant. Pluto nium residues stored in 55-gallon drums were packaged for short-term storage until the residues could be processed for plutonium recovery. These residues have now been determined by the Department of Energy to be waste materials, and the residues will remain in storage until plans for disposal of the material can be developed. The packaging configurations which were safe for short-term storage may not be safe for long-term storage. Interviews with Rocky Flats personnel involved with packaging the residues reveal that more than one packaging configuration was used for some of the residues. A tabulation of packaging configurations was developed based on the information obtained from the interviews. A number of potential safety problems were identified during this study, including hydrogen generation from some residues and residue packaging materials, contamination containment loss, metal residue packaging container corrosion, and pyrophoric plutonium compound formation. Risk factors were developed for evaluating the risk potential of the various residue categories, and the residues in storage at Rocky Flats were ranked by risk potential. Preliminary drum head space gas sampling studies have demonstrated the potential for formation of flammable hydrogen-oxygen mixtures in some residue drums.

\section{SUMMARY}

When plutonium operations at Rocky Flats were curtailed in December 1989, a large number of residue drums stored in the drum backlog were awaiting processing. Most of these residues had been packaged assuming they would be processed fairly quickly and would remain in storage for, at most, a few years. Plutonium operations at Rocky Flats have now been curtailed for over four years, and several more years will be required before any operations to process the residue drum backlog can be started. Since the residues have already been stored far longer than was originally planned, concerns have been raised about the safety risks involved in continued storage of these residues. Therefore, a study was conducted to evaluate the risks involved with continued storage of the residues in the drum backlog.

This study was conducted by first developing a database which contained information on all of the 55-gallon residue drums currently stored in the backlog. This database was developed by combining information from the Safeguards and Accountability Network (SAN) and the Waste and Environmental Management System (WEMS). The new database was developed because early in the study the fact became apparent that neither the SAN nor the WEMS databases contained all of the information required for a residue drum safety study.

The next step in the residue drum safety study was to obtain information on the packaging configurations used for the various residue Item Description Code (IDC) categories. The residue packaging configuration information was obtained from data in waste packaging procedures WO-4034, "Radioactive Waste Packaging Requirements," and WO-1100, "Solid Radioactive Waste Packaging Inside the PA," and by conducting interviews with operations personnel who have worked in the process areas for a number of years. These interviews revealed that for many of the residue categories, several different packaging configurations have been used for the same residue.

Risk factors were then developed which identified the potential risks associated with residues stored in the drum backlog. These risk factors are (1) gas generation, (2) contamination containment loss, (3) drum and residue packaging corrosion, and (4) reactive metals and compounds. 
Several potential mechanisms were identified for gas generation in residue drums. These mechanisms include (1) radiolysis of water, (2) radiolytic degradation of organic material, (3) acidmetal reactions between mild steel drums and acid vapors, and (4) reaction of water with reactive metals. These gas generation mechanisms result in the generation of hydrogen, carbon dioxide, carbon monoxide, and other gases.

Contamination containment loss occurs from degradation of plastic packaging materials by heat, radiation, and acid vapors. Heat, radiation, and acid vapors can also degrade the adhesive on the tape used to seal plastic bags, which can result in seal loss.

Fifty-five gallon drum and drum-vent filter assembly corrosion occurs as a result of attack by acid vapors or chlorinated solvents from residues containing residual acid or solvents. Corrosion of metal cans used to store chloride salt residue can occur if the salts absorb moisture.

Some pyrochemical salt residues contain residual plutonium metal that may react with water in the drum atmosphere to produce compounds such as plutonium hydride or plutonium oxide hydride that are more pyrophoric than plutonium metal. Strong nitric acid reacts with the lead oxide layer in leaded drybox gloves to produce compounds that are highly flammable and shock sensitive when dried.

Each of the residue IDC categories was evaluated to determine which of the risk factors might be associated with that particular IDC. The IDC categories were then assigned a risk potential, based upon the number of risk factors associated with the IDC and an estimate of the magnitude of the risk associated with each risk factor for the IDC. Risk potentials of one to five were used for ranking the IDC categories, with one being the highest risk potential and five being the lowest. IDC categories with no risk factors were given a risk potential of five. The residue categories that were assigned a risk potential of one were skulls, non-spec oxide, peroxide cake, Ful-Flo filters, wet combustibles, electrorefining salts, unpulverized molten salt extraction salts, several miscellaneous pyrochemical salt categories, and acid-contaminated leaded drybox gloves.

The residue drum safety study identified no imminent safety hazards. However, the potential safety risks that were identified appear to be sufficiently real to warrant further investigation. These potential safety risks include (1) residue drum pressurization, (2) residue drum hydrogen accumulation, (3) contamination containment loss in residue packages and drums, (4) drum and drum-vent filter assembly corrosion, (5) metal residue container corrosion, and (6) pyrophoric or unstable compound formation in drums containing plutonium or reactive metals. While a number of potential mechanisms were identified that could result in safety risks, other factors were also identified which could offset the identified risks. The conclusion was that all the information required to determine the extent of the hazard posed by these potential safety risks is not currently available. 


\section{INTRODUCTION}

Plutonium operations at Rocky Flats were curtailed following the inventory conducted in November 1989. At that time, the curtailment was expected to last only for a few months. The curtailment has now lasted for over four years, and several more years will be required before any operations dealing with the residue drum backlog can be started. Most of the residues in the drum backlog were packaged assuming they would remain in storage for a few months to, at most, a few years. Some of these residues have been in storage for over 10 years, and none of the residues have been in storage less than three years. Since the residues have already been stored far longer than was originally planned, concerns have been raised about the safety risks involved in their continued storage.

Because of these concerns, a study was conducted to evaluate potential risks involved with continued residue storage in the drum backlog and to recommend actions to be taken to determine whether any potential risks actually exist. The study was limited to residues stored in 55gallon drums because other studies are being conducted to identify storage risks for material stored in vaults and 10-gallon drums. This study was conducted by first developing a database which contained information on all 55-gallon drums currently stored in the backlog that were listed as residue drums in the Waste Type field in the Waste and Environmental Management System (WEMS) database. Most Item Description Code (IDC) categories contain both residue and waste drums. However, in many cases, the drums of potential concern are those drums containing the most plutonium. Conclusions reached concerning residue drums can be applied to waste drums in the same IDC if the concern is independent of plutonium concentration.

Packaging configuration information used for the residue drums was obtained from Rocky Flats Plant waste packaging procedures and from interviews conducted with operations personnel who have worked in the process areas for a number of years. These interviews revealed some inconsistencies in the packaging configurations used. For a given IDC, more than one packaging configuration may exist in the residue drum backlog. However, a table was developed showing the most probable packaging configuration for the various IDCs, based upon waste packaging procedure information and the operations personnel interviews. This table also contains probable alternate packaging configuration information for some of the IDCs.

Several risk factors were developed which identified the potential risks associated with residues stored in the drum backlog. Each IDC was then evaluated to determine if any of the risk factors applied. Each IDC was assigned a risk potential of one to five based upon the risk factors, with one being the highest risk potential and five being the lowest. The IDCs were then ranked by risk potential. After the IDCs had been evaluated and ranked, recommendations for verifying the existence of the identified risks were developed.

The purpose of this report is to document the methodology used for the residue drum safety study and to describe the results of the study. The report describes the database development work, the risk factors development, and the ranking of the IDCs by risk potential. Recommendations for verifying the existence of the identified risks are given at the end of the report.

\section{DATABASE DEVELOPMENT}

The first step in the residue drum safety study was to obtain information on the drums stored in the residue drum backlog. Currently two databases at Rocky Flats contain information on residue drums. These databases, Safeguards Accountability Network (SAN) and Waste and Environmental Management System (WEMS), designed for different purposes, are incompatible with each other. Each contains useful information for the residue drum safety study; however, 
no easy way existed to correlate their information. In addition, some of the information required for the residue drum safety study is not contained in either database. For example, neither the SAN nor the WEMS database contains information on the packaging configurations existing in residue drums. Early in the study the need for a new database containing the information required for the residue drum safety study became apparent.

A residue drum database was developed by SNM Management personnel by combining information from the SAN and WEMS databases. New database development was started by compiling SAN data from all packages of material in the residue IDCs. These data were then sorted to eliminate all material not stored in 55-gallon drums. WEMS database information was then compiled for all 55-gallon drums in the residue IDCs. The WEMS data were sorted to extract the drums identified as residue drums in the Waste Type field. The WEMS data for these residue drums were then combined with the SAN data. This new residue drum database was then sorted by IDC in various ways to prepare the tables contained in this report.

\section{RESIDUE PACKAGING}

General packaging requirements for Rocky Flats generated waste are contained in Waste Operations procedure WO-4034, "Radioactive Waste Packaging Requirements." Specific requirements for packaging waste generated in the Protected Area (PA) at Rocky Flats are given in Waste Operations proccedure WO-1100, "Solid Radioactive Waste Packaging Inside the PA." WO-4034 has been in existence for a number of years, but WO-1100 was developed only a few years ago. Most drum backlog residue was generated prior to the development of WO-1100, and waste and residue packaging requirements have changed several times in the past 10 to 15 years. Because of these changes, multiple packaging configurations exist in the residue drum backlog. To gain a better understanding of these packaging configurations, interviews were conducted with Operations and other personnel who were involved with residue packaging operations during the time when most of the drum backlog residue was generated.

A matrix was developed which contained the type of containers and packaging materials known to have been used over the years for packaging residues. The personnel who were interviewed were asked to check the types of packaging material used for the various IDC categories. The completed matrix forms were then evaluated to determine the most probable packaging configurations; this packaging configuration information is given in Table 1. Table 1 is constructed to show the inner most packaging containers first. Moving from left to right across the table, subsequent layers of packaging materials are shown. The last column is for the rigid liner, which is the last layer of packaging inside the 55-gallon drum.

For each IDC, an "X" is placed in the columns to the right of the IDC description that corresponds to the most probable packaging materials used for residue in the IDC category. If probable alternate packaging material was identified during the evaluation, an " $A$ " is placed in the column for that material. For example, most people interviewed indicated that incinerator sludge, IDC 292, is packaged in four-liter plastic bottles which were removed from the glovebox using a polyvinyl chloride (PVC) O-ring bag, which was sealed with yellow tape. The bagged four-liter bottle was then placed in a polyethylene bag sealed with tape, and the double-bagged bottle was then placed in a drum lined with one 55-gallon drum liner and one round-bottom drum liner. However, one of the people interviewed indicated that the double-bagged bottle was placed in a clam shell before being placed in the drum. Therefore, the clam shell column for incinerator sludge contains an " $\mathrm{A}$," indicating that some of the double-bagged, four-liter bottles of incinerator sludge are contained in a clam shell. Another person stated that rigid liners 
Table 1

PROBABLE PACKAGING CONFIGURATION FOR RESIDUE IDCS IN DRUM BACKLOG

\begin{tabular}{|c|c|c|c|c|c|c|c|c|c|c|c|c|}
\hline $\mathrm{IDC}$ & DESCRIPTION & $\begin{array}{l}\text { FREE- } \\
\text { ZETTE } \\
\text { (1) }\end{array}$ & $\begin{array}{l}\text { 2OR 4L } \\
\text { BOTTLE }\end{array}$ & $\begin{array}{l}8801 \\
\text { CAN }\end{array}$ & $\begin{array}{l}\text { PVC } \\
\text { O-RING } \\
\text { BAG } \\
\end{array}$ & $\begin{array}{l}\text { POLY- } \\
\text { ETHYIENE } \\
\text { BAG }\end{array}$ & $\begin{array}{l}8802 \\
\text { CAN }\end{array}$ & $\begin{array}{l}\text { CLAM- } \\
\text { SHELL }\end{array}$ & $\begin{array}{l}\text { CARD } \\
\text { BOARD } \\
\text { LNNR }\end{array}$ & $\begin{array}{l}55 \mathrm{GAL} \\
\text { LINER }\end{array}$ & $\begin{array}{l}\text { ROUND } \\
\text { BOTTOM } \\
\text { LNER } \\
\end{array}$ & $\begin{array}{l}\text { RIGD } \\
\text { LNER }\end{array}$ \\
\hline 025 & AL ALLOY ANODE HEEL FOR SRP & & & $\mathbf{x}$ & $\mathbf{x}$ & & $\mathbf{x}$ & & & $\mathbf{x}$ & $\mathbf{x}$ & \\
\hline 050 & SKULLS & & & $\mathbf{x}$ & $\mathbf{x}$ & & $\mathbf{x}$ & & & $\mathbf{x}$ & $\mathbf{x}$ & \\
\hline 061 & NON-SPEC OXIDE & & & $\mathbf{x}$ & $\mathbf{x}$ & & $\mathbf{x}$ & & & $\mathbf{x}$ & $\mathrm{x}$ & \\
\hline 080 & PEROXIDECAKE & & & $\mathbf{x}$ & $\mathbf{x}$ & & $\mathbf{x}$ & & & $\mathbf{x}$ & $\mathbf{x}$ & \\
\hline 200 & STANDARDS & & $X(4 L)$ & & & & & & & $\underline{\mathbf{x}}$ & $\mathbf{x}$ & \\
\hline 290 & FLTER SLUDGE & $\mathbf{x}$ & $A(4 L)$ & A & $\mathbf{x}$ & $\mathbf{x}$ & $\mathbf{x}$ & & & $\mathbf{x}$ & $\underline{\mathbf{x}}$ & A \\
\hline 292 & INCNERATOR SLUDGE & & $X(4 L)$ & & $\mathbf{x}$ & $\mathbf{x}$ & & A & & $\mathbf{x}$ & $x$ & A \\
\hline 299 & MISCELLANEOUS SLUDDEE & $\mathbf{x}$ & & & $\mathbf{x}$ & $\mathbf{x}$ & $\mathbf{x}$ & & & $\mathbf{x}$ & $\mathbf{x}$ & A \\
\hline 300 & GRAPHITE MOLDS & & & & $\mathbf{x}$ & $\mathbf{x}$ & & & $\mathbf{x}$ & $\mathbf{x}$ & $\mathbf{x}$ & \\
\hline 301 & CLASSIFIED GRAPHTTE SHAPES & & & & $\mathbf{x}$ & $\mathbf{x}$ & & & $\mathbf{x}$ & $\mathbf{x}$ & $\mathbf{x}$ & \\
\hline 303 & SCARFED GRAPHITE CHUNKS & & & & & & & & $\mathbf{x}$ & $\mathbf{x}$ & $\mathbf{x}$ & \\
\hline 310 & GRAPHITE SCARFINGS AND FINES & & $X(2 L)$ & & $\mathbf{x}$ & $\mathbf{x}$ & & & & $\mathbf{x}$ & $\mathbf{x}$ & \\
\hline 312 & GRAPHTTE, COURSE & & $X(4 \mathrm{~L})$ & & $\mathbf{x}$ & $\mathbf{x}$ & & & & $\mathbf{x}$ & $\underline{x}$ & \\
\hline 320 & HEAVY NON-SS METAL $\left(T_{a}, W, P l\right)$ & & & & $\mathbf{x}$ & $\mathbf{x}$ & & & $\mathbf{x}$ & $\mathbf{x}$ & $\mathbf{x}$ & $\mathbf{x}$ \\
\hline 330 & COMBUSTIBLES, DRY & & & & $\mathbf{x}$ & $\mathrm{x}$ & & & & $\mathbf{x}$ & $\mathbf{x}$ & \\
\hline 331 & FLTER, FUL FLO, NOT FROM INCINERATOR & & $\mathrm{A}(4 \mathrm{~L})$ & & $\mathbf{x}$ & $\mathbf{x}$ & & $\mathbf{x}$ & & $\mathbf{x}$ & $\mathbf{x}$ & $\mathbf{x}$ \\
\hline 332 & OLLYSLUDGE & & & $\mathbf{x}$ & $\mathbf{x}$ & $\mathbf{x}$ & $\mathbf{x}$ & & & $\mathbf{x}$ & $\underline{\mathbf{x}}$ & \\
\hline 333 & CALCIUMMETAL & $\mathbf{A}$ & & $\mathbf{x}$ & $x$ & $\mathbf{x}$ & $\mathrm{x}$ & & $\mathrm{x}$ & $\mathbf{x}$ & $\mathbf{x}$ & \\
\hline 334 & BLAANKET, FIRE & & & & $\mathbf{x}$ & $\mathbf{x}$ & & & & $\mathbf{x}$ & $\mathbf{x}$ & \\
\hline 335 & DRYBOX FLLTERS, NOT ACID CONTAMINATED & & & & $\mathbf{x}$ & $\mathbf{x}$ & & & $\mathrm{x}$ & $\mathbf{x}$ & $\mathbf{x}$ & $\mathbf{A}$ \\
\hline
\end{tabular}

X-Indicates items used in most likely packaging configuration.

A-Indicates items that may have been used in altemate packaging configurations.

(1) A freezette is a quart size food storage container with a locking lid. 
Table 1 (Continued)

PROBABLE PACKAGING CONFIGURATION FOR RESIDUE IDCS IN DRUM BACKLOG

\begin{tabular}{|c|c|c|c|c|c|c|c|c|c|c|c|c|}
\hline $\mathbb{D C}$ & DESCRIPTION & $\begin{array}{l}\text { FREE- } \\
\text { ZETIE }\end{array}$ & $\begin{array}{l}2 \text { OR 4I } \\
\text { BOTTLE }\end{array}$ & $\begin{array}{l}8801 \\
\text { CAN }\end{array}$ & $\begin{array}{l}\text { PVC } \\
\text { O-RING } \\
\text { BAG }\end{array}$ & $\begin{array}{l}\text { POLY- } \\
\text { ETHYLNE } \\
\text { BAG }\end{array}$ & $\begin{array}{l}8802 \\
\mathrm{CAN}\end{array}$ & $\begin{array}{l}\text { CLAM- } \\
\text { SHELL }\end{array}$ & $\begin{array}{l}\text { CARD } \\
\text { BOARD } \\
\text { LNERR } \\
\end{array}$ & $\begin{array}{l}\text { 55GAL } \\
\text { LNERR }\end{array}$ & $\begin{array}{l}\text { ROUND } \\
\text { BOTTOM } \\
\text { LINER }\end{array}$ & $\begin{array}{l}\text { RIGID } \\
\text { LINERR }\end{array}$ \\
\hline 336 & COMBUSTIBLES, WET & & & & $\mathbf{x}$ & $\mathbf{x}$ & & A & & $\underline{x}$ & $\underline{x}$ & $\mathbf{A}$ \\
\hline 337 & PLASTIC & & & & $\mathbf{x}$ & $\mathbf{x}$ & & & & $\mathbf{x}$ & $\mathbf{x}$ & \\
\hline 338 & FILTER MEDIA & & & & $\mathbf{x}$ & $x$ & & & & $\mathbf{x}$ & $\underline{x}$ & \\
\hline 339 & LEADED GLOVES, NOT ACID CONTAMINATED & & & & $\mathbf{x}$ & $x$ & & & & $\underline{\mathbf{x}}$ & $\underline{x}$ & $\mathbf{x}$ \\
\hline 340 & SLUDGE FROM SZZE REDUCTION AREA & $\mathbf{x}$ & & & $\mathrm{x}$ & $\mathbf{x}$ & $\mathbf{x}$ & & & $\mathbf{x}$ & $x$ & \\
\hline 341 & LEADED GLOVES, ACD CONTAMINATED & & & & $\mathbf{x}$ & $\mathbf{x}$ & & & & $\mathbf{x}$ & $\underline{x}$ & $\mathbf{x}$ \\
\hline 342 & DRYBOX FLTERS, ACDD CONTAMINATED & & & & $x$ & $x$ & & & $\mathbf{A}$ & $\mathbf{x}$ & $\underline{x}$ & A \\
\hline 360 & $\mathrm{AL}_{2} \mathrm{O}_{3}$ CERAMIC CRUCIBLES & & $x$ & & $\mathbf{x}$ & $\mathbf{x}$ & & $\mathbf{x}$ & & $\mathbf{x}$ & $\mathbf{x}$ & \\
\hline 363 & ELECTROREFINING SALT, FIRST USE & A & A & $\mathbf{X}(1)$ & $\mathbf{x}$ & $\mathrm{x}$ & $x(2)$ & A & & $\mathbf{x}$ & $\underline{x}$ & \\
\hline 364 & ELECTROREFINING SALT. SECOND USE & A & $\mathbf{A}$ & $\mathbf{X}(1)$ & $\mathbf{x}$ & $\mathrm{x}$ & $\mathbf{x}(2)$ & A & & $\underline{x}$ & $\mathbf{x}$ & \\
\hline 365 & SALT FROM BAD DOR RUN & $\mathbf{A}$ & A & $\mathbf{X}(1)$ & $x$ & $\mathrm{x}$ & $x(2)$ & A & & $x$ & $x$ & \\
\hline 368 & MgO CRUCIBLES, NOT LECO & & $\mathbf{x}$ & & $\mathbf{x}$ & $\mathbf{x}$ & & $\mathbf{x}$ & & $\mathbf{x}$ & $\mathbf{x}$ & \\
\hline 369 & LECO HEEL & $x$ & & & $\mathbf{x}$ & $\mathrm{x}$ & $\mathbf{x}$ & & & $\mathbf{x}$ & $x$ & \\
\hline 370 & LECO CRUCIBLES & & $A(4 L)$ & & $\mathbf{x}$ & $x$ & (3) & & & $x$ & $\underline{x}$ & \\
\hline 371 & FIREBRRICK & & (4) & & $x$ & $\mathrm{x}$ & & & & $\mathbf{x}$ & $\mathbf{x}$ & \\
\hline 372 & GRT & & $x(2 L)$ & & $\mathrm{x}$ & $\mathrm{x}$ & & & & $x$ & $\underline{x}$ & \\
\hline 373 & FIREBRICK HEEL & A & $\mathrm{x}$ & & $x$ & $x$ & & & & $\mathbf{x}$ & $\mathbf{x}$ & \\
\hline 376 & PROCESSED FILTER MEDIA & & $\mathbf{x}$ & & $x$ & $\mathrm{x}$ & & A & & $\mathbf{x}$ & $\mathbf{x}$ & \\
\hline 377 & FIREBRICK, COARSE & & (4) & & $\mathrm{x}$ & $x$ & & & & $\mathrm{x}$ & $\mathbf{x}$ & \\
\hline 378 & FIREBRICK, PULVERIZED OR FINES & & & $\mathbf{x}$ & $\mathrm{x}$ & $\mathbf{x}$ & $\mathbf{x}$ & & & $\mathbf{x}$ & $\mathbf{x}$ & \\
\hline
\end{tabular}

X-Indicates items used in most likely packaging configuration.

A-Indicates items that may have been used ta alem produce can
(1)-Stainless steel (SS) 8801 can or tin plated steel 8802 can or 1 gallon paint can

(3)-Tin plated steel, 1 gallon paint can (4)-10 gallon fiberboard container 
PROBABLE PACKAGING CONFIGURATION FOR RESIDUE IDCS IN DRUM BACKLOG (CONTINUED)

\begin{tabular}{|c|c|c|c|c|c|c|c|c|c|c|c|c|}
\hline IDC & DESCRIPTION & $\begin{array}{l}\text { FREE- } \\
\text { ZETIE }\end{array}$ & $\begin{array}{l}\text { 2OR 4L } \\
\text { BOTTLE }\end{array}$ & $\begin{array}{l}8801 \\
\text { CAN }\end{array}$ & $\begin{array}{l}\text { PVC } \\
\text { O-RING } \\
\text { BAG }\end{array}$ & $\begin{array}{l}\text { POLY- } \\
\text { EIHYLENE } \\
\text { BAG }\end{array}$ & $\begin{array}{l}8802 \\
\text { CAN }\end{array}$ & $\begin{array}{l}\text { CLAM- } \\
\text { SHELLL }\end{array}$ & $\begin{array}{l}\text { CARD } \\
\text { BOARD } \\
\text { LNER }\end{array}$ & $\begin{array}{l}\text { S5GAL } \\
\text { UNERR }\end{array}$ & $\begin{array}{l}\text { ROUND } \\
\text { BOTTOM } \\
\text { INER } \\
\end{array}$ & $\begin{array}{l}\text { RIGD } \\
\text { LNERR }\end{array}$ \\
\hline 390 & UNPULVERRIZEDSLAG & & $\underline{x}$ & A & $\mathbf{x}$ & $\mathbf{x}$ & A & & $\mathbf{x}$ & $\mathbf{x}$ & $\mathbf{x}$ & \\
\hline 391 & UNPULVERIZED SAND AND CRUCIBLE & & $\mathbf{x}$ & & $x$ & $\mathbf{x}$ & & $\mathbf{x}$ & $\mathbf{x}$ & $\mathbf{x}$ & $\mathbf{x}$ & \\
\hline 392 & UNPULVERRZZED SAND, SLAG, AND CRUCIBLE & & $\mathbf{x}$ & & $\mathbf{x}$ & $\mathbf{x}$ & & $\mathbf{x}$ & $\mathbf{x}$ & $\underline{\mathbf{x}}$ & $\mathbf{x}$ & \\
\hline 393. & SAND, SLAG, AND CRUCTBLE HEEL & & $\mathbf{x}$ & A & $\mathbf{x}$ & $\mathbf{x}$ & A & $\mathbf{x}$ & $\underline{\mathbf{x}}$ & $\mathbf{x}$ & $\underline{\mathbf{x}}$ & \\
\hline 394 & SAND FROM BUTTON BREAKOUT & & $\mathbf{x}$ & A & $\mathbf{x}$ & $\mathbf{x}$ & A & A & $\mathbf{x}$ & $\mathbf{x}$ & $\mathbf{x}$ & \\
\hline 398 & PULVERTZED SS\&C & & $\underline{\mathbf{x}}$ & A & $\mathbf{x}$ & $\mathbf{x}$ & A & $\mathbf{x}$ & $\mathbf{x}$ & $\mathbf{x}$ & $\underline{x}$ & \\
\hline 404 & MOLTEN SALT, $\mathrm{Ca}, \mathrm{Zn}, \mathrm{K}$ & & $\mathrm{x}$ & & $\mathrm{x}$ & $\mathbf{x}$ & & $\mathbf{x}$ & & $x$ & $\underline{\mathbf{x}}$ & \\
\hline 405 & MOLTEN SALT, UNKNOWN \% UNPULVERTZED & A & A & $x(1)$ & $\mathrm{x}$ & $\mathbf{x}$ & $x(2)$ & A & & $\mathbf{x}$ & $\mathbf{x}$ & \\
\hline 407 & MOLTEN SALT, 8\% UNPULVERTEED & $\mathbf{A}$ & A & $x(1)$ & $\underline{x}$ & $\underline{\mathbf{x}}$ & $x(2)$ & A & & $\mathbf{x}$ & $x$ & \\
\hline 408 & MOLTEN SALT, 8\% PULVERIZED & A & A & $x(1)$ & $\mathbf{x}$ & $\mathbf{x}$ & $x(2)$ & $\mathbf{A}$ & & $\mathbf{x}$ & $\underline{x}$ & \\
\hline 409 & MOLTEN SALT, $30 \%$ UNPULVERIZED & A & A & $\mathbf{x}(1)$ & $\mathbf{x}$ & $\mathbf{x}$ & $x(2)$ & A & & $\underline{\mathbf{x}}$ & $\mathbf{x}$ & \\
\hline 410 & MOLTEN SALT, 30\% PULVERIZED & A & A & $\mathbf{X}(1)$ & $\mathbf{x}$ & $\underline{x}$ & $x(2)$ & A & & $\underline{x}$ & $\underline{x}$ & \\
\hline 411 & ELECTROREFINING SALT, FINAL DISPOSTTION & A & A & $x(1)$ & $x$ & $\mathbf{x}$ & $\mathbf{x}(2)$ & A & & $\mathbf{x}$ & $\mathbf{x}$ & \\
\hline 412 & GIBSONSALT & A & A & $x(1)$ & $\mathbf{x}$ & $\mathbf{x}$ & $x(2)$ & $\mathbf{A}$ & & $\mathbf{x}$ & $\mathbf{x}$ & \\
\hline 413 & IMPURE SALT FROM CELL CLEANOUT & A & A & $x(1)$ & $\mathbf{x}$ & $\underline{x}$ & $x(2)$ & $\mathbf{A}$ & & $\mathbf{x}$ & $\mathbf{x}$ & \\
\hline 414 & DOR SALT, UNOXIDIZED Ca & A & A & $x(1)$ & $\underline{x}$ & $\mathbf{x}$ & $\mathbf{x}(2)$ & $\mathbf{A}$ & & $\mathbf{x}$ & $\mathbf{x}$ & \\
\hline 415 & PLUTONIUM CHLORIDE MIXED SALT & $\mathbf{A}$ & A & $x(1)$ & $\mathbf{x}$ & $\mathbf{x}$ & $X(2)$ & $\mathbf{A}$ & & $\underline{x}$ & $\mathbf{x}$ & \\
\hline 417 & DICESTUM HEXACHLOROPLUTONATESALT & $\mathbf{x}$ & & & $\mathbf{x}$ & $\mathbf{x}$ & $\mathbf{x}$ & & & $\underline{x}$ & $\underline{x}$ & \\
\hline 419 & UNPUL VERZZED NCINERATOR ASH & & $\mathbf{x}$ & & $\mathbf{x}$ & $\mathbf{x}$ & & $\mathbf{x}$ & & $\mathbf{x}$ & $\mathbf{x}$ & \\
\hline 420 & PULVERIZED INCINERATOR ASH & & $\mathbf{x}$ & & $\mathbf{x}$ & $\mathbf{x}$ & & $\mathbf{x}$ & $\mathbf{A}$ & $\mathbf{x}$ & $\mathbf{x}$ & \\
\hline
\end{tabular}

X-Indicates items used in most likely packaging configuration.

A-Indicates items that may have been used in altemate packaging configurations.
$\begin{array}{llll}\text { (1)-Stainless steel (S/S) } 8801 \text { can or tin plated steel produce can } & \text { (2)-(SS) } 8802 \text { can or } 1 \text { gallon paint can }\end{array}$ 
PROBABLE PACKAGING CONFIGURATION FOR RESIDUE IDCS IN DRUM BACKLOG

\begin{tabular}{|c|c|c|c|c|c|c|c|c|c|c|c|c|}
\hline IDC & DESCRIPTION & $\begin{array}{l}\text { FREE- } \\
\text { ZZETIE }\end{array}$ & $\begin{array}{l}2 \text { OR 4L } \\
\text { BOTTLE }\end{array}$ & $\begin{array}{l}8801 \\
\mathrm{CAN}\end{array}$ & $\begin{array}{l}\text { PVC } \\
\text { ORING } \\
\text { BAG } \\
\end{array}$ & $\begin{array}{l}\text { POLY- } \\
\text { ETHYLENE } \\
\text { BAG }\end{array}$ & $\begin{array}{l}8802 \\
\text { CAN }\end{array}$ & $\begin{array}{l}\text { CLAM } \\
\text { SHELL L }\end{array}$ & $\begin{array}{l}\text { CARD } \\
\text { BOARD }\end{array}$ & $\begin{array}{l}55 \mathrm{GAL} \\
\text { LNERR }\end{array}$ & $\begin{array}{l}\text { ROUND } \\
\text { BOTTOM } \\
\text { LNER }\end{array}$ & $\begin{array}{l}\text { RIGID } \\
\text { LINER }\end{array}$ \\
\hline 421 & ASH HEEL & & $\mathbf{x}$ & & $\mathbf{x}$ & $\mathbf{x}$ & & $\mathbf{x}$ & & $\mathbf{x}$ & $\mathbf{x}$ & \\
\hline 422 & soor & $\mathbf{x}$ & & & $\mathbf{x}$ & $\mathbf{x}$ & & & & $\mathbf{x}$ & $\mathbf{x}$ & \\
\hline 426 & RERURNED IDC 413 & & $\mathbf{x}$ & $\mathbf{A}$ & $x$ & $\mathrm{x}$ & A & $\underline{x}$ & & $\underline{x}$ & $\dot{x}$ & \\
\hline 427 & MSE SPENT DICESIUMSALT & & & $\mathbf{X}(1)$ & $\mathbf{x}$ & $\underline{x}$ & $\mathbf{x}(2)$ & & & $\mathbf{x}$ & $\mathbf{x}$ & \\
\hline 428 & ASH SELECTED FOR MMEC & & $\mathbf{x}$ & & $\mathbf{x}$ & $\mathbf{x}$ & & & & $\mathbf{x}$ & $\underline{x}$ & \\
\hline 429 & SCRUB ALLOY SPENT SALT & & $\mathbf{x}$ & & $\mathbf{x}$ & $\mathbf{x}$ & & $\mathbf{x}$ & & $\mathbf{x}$ & $\mathbf{x}$ & \\
\hline 431 & RESIN, LEACHED & & (3) & $\mathbf{A}$ & $\underline{x}$ & $\underline{x}$ & & & & $\mathbf{x}$ & $\underline{x}$ & \\
\hline 433 & SCRUB ALLOY SPENT DICESIUM SALT & & $\mathbf{x}$ & & $\underline{x}$ & $\mathbf{x}$ & & $\mathbf{x}$ & & $\mathbf{x}$ & $\mathbf{x}$ & \\
\hline 434 & FREE CALCIUM CONTAINING SPENT SALT & & $\mathbf{x}$ & & $\mathbf{x}$ & $\mathrm{x}$ & & $\mathbf{x}$ & & $\mathbf{x}$ & $\mathbf{x}$ & \\
\hline 438 & INSULATION & & & & $\mathbf{x}$ & $\mathbf{x}$ & & & & $\mathbf{x}$ & $\mathbf{x}$ & \\
\hline 440 & GLASS (EXCEPT RASCHIG RINGS) & & $\mathbf{x}$ & & $x$ & $\mathbf{x}$ & & & $\mathbf{x}$ & $\underline{x}$ & $\mathbf{x}$ & $\mathbf{A}$ \\
\hline 441 & UNLEACHED RASCHIG RINGS & & & & $\mathbf{x}$ & $\underline{x}$ & & & $\underline{x}$ & $\underline{x}$ & $\mathbf{x}$ & \\
\hline 442 & LEACHED RASCHIG RINGS & & & & $\mathbf{x}$ & $\underline{x}$ & & & $\mathbf{x}$ & $\underline{\mathbf{x}}$ & $\mathbf{x}$ & \\
\hline 473 & ER SALT PACKAGED FOR LANL & & $\mathbf{x}$ & & $\mathbf{x}$ & $\mathbf{x}$ & & $\mathbf{x}$ & & $\mathbf{x}$ & $\mathbf{x}$ & \\
\hline 480 & LGHTMETAL & & & & $\mathrm{x}$ & $\underline{x}$ & & & $\underline{x}$ & $\mathbf{x}$ & $\mathrm{x}$ & A \\
\hline 490 & HEPA FLTERS (24X24), NOT ACID CONTAMNATED & & & & $\mathbf{x}$ & $\mathbf{x}$ & & & (4) & $\mathbf{x}$ & $\mathrm{x}$ & \\
\hline 654 & ER SALT FROM Pu/Np & & & $X(1)$ & $x$ & $\mathrm{x}$ & $X(2)$ & & & $\underline{x}$ & $\underline{x}$ & \\
\hline 655 & ER CERAMICS FROM Pu/Np & & $\mathbf{x}$ & & $\mathrm{x}$ & $\mathbf{x}$ & & $\mathbf{x}$ & & $\mathbf{x}$ & $\mathbf{x}$ & \\
\hline
\end{tabular}

X-Indicates items used in most likely packaging configuration.

A-Indicates items that may have been used in altemate packaging configurations.

$\begin{array}{ll}\text { (1)-Stainless steel (S/S) } 8801 \text { can or tin plated steel produce can } & \text { (2)-S/S } 8802 \text { can or } 1 \text { gallon paint can } \\ \text { (3)-Kraft tube (10 gallon fiberboard container) } & \text { (4)-Cardboard box }\end{array}$

(3)-Kraft tube (10 gallon fiberboard container) 
Figure 1

\section{RESIDUE PACKAGING CLAM SHELL}

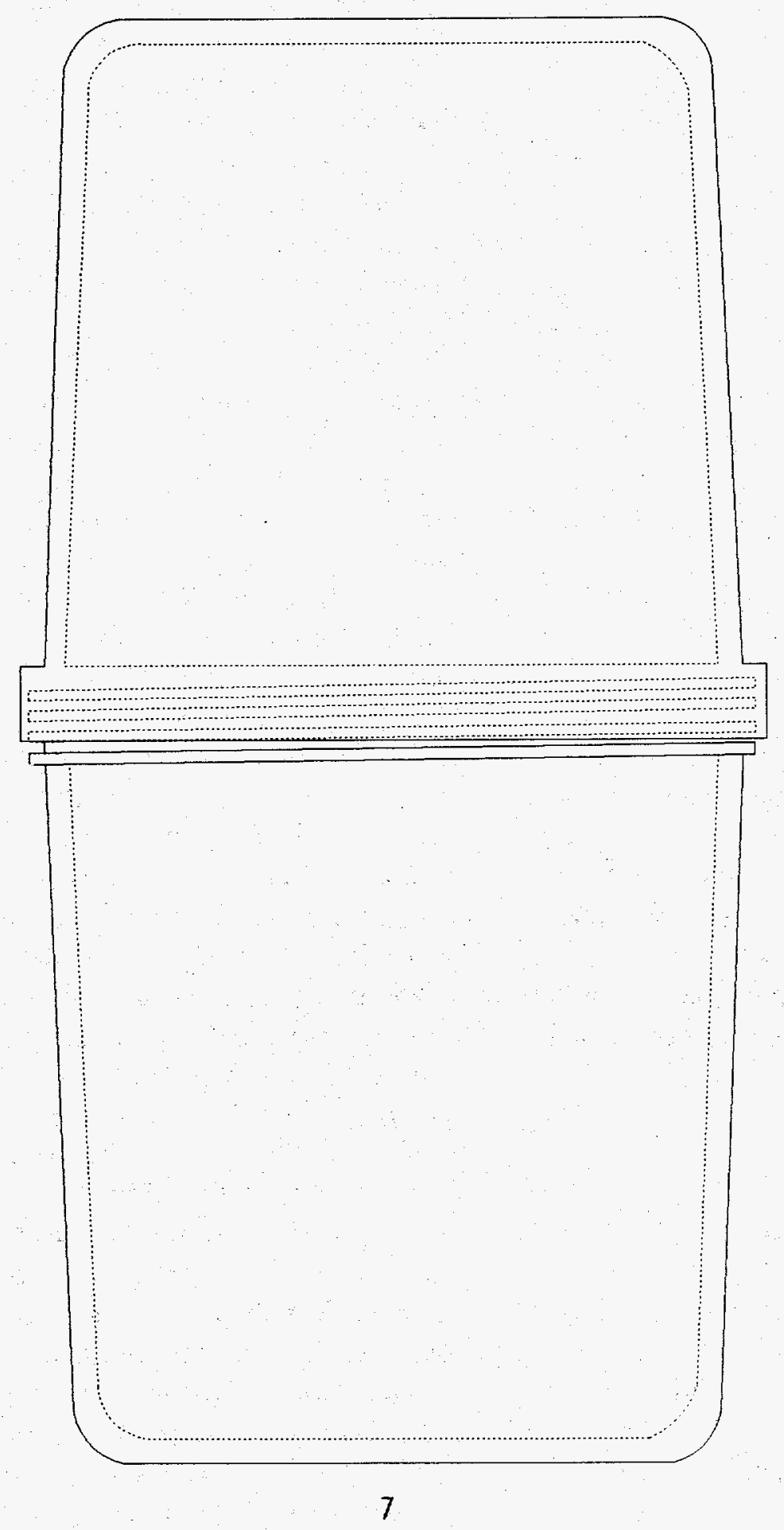


were used for incinerator sludge drums; therefore, the rigid liner column for incinerator sludge contains an "A."

A clam shell is a seven-inch diameter by 14-inch tall polyethylene container with threads in the middle of the container (see Figure 1). Clam shells are used to package residue that might contain free liquids. Examples of residues that are packaged in clam shells are sludge, Ful-Flo filters, and wet combustibles.

Table 1 indicates that all of the residue drums contain one 55-gallon liner and one roundbottom drum liner. However, some of the people interviewed indicated that some of the drums were prepared using a second 55-gallon liner in place of the round-bottom liner. Packaging configurations for some of the residue IDC categories in the drum backlog probably are not reflected in Table 1; however, the information in Table 1 reflects the packaging configuration for most of the residues in the various IDC categories.

\section{RISK FACTORS}

Risk factors for drums in the residue drum backlog were developed based upon the author's research and development and plutonium processing experience and upon interviews with Operations, Process Technology and Support, and other personnel with plutonium processing and handling experience. Risk factors developed for this study are listed below and discussed in the following sections.

\section{Gas Generation}

\section{Contamination Containment Loss}

\section{Drum and Residue Packaging Corrosion}

\section{Reactive Metals and Compounds}

Some residue categories have the potential for more than one of the risk factors. For example, some drums of Ful-Flo filters could have three of the four risk factors.

\section{Gas Generation}

Gas generation in residue drums can result in two potential problems:

(1) pressurization of the drum or the packages in the drum, and (2) accumulation of hydrogen in the drum. Gas generation can result from four sources: (1) radiolytic decomposition of water and organic materials, (2) acid-metal reactions, (3) bacterial reactions with organic materials, ${ }^{1}$ and (4) reaction of water with reactive metals. Radiolytic decomposition of water produces hydrogen and oxygen, and radiolytic decomposition of organic materials can produce hydrogen, in addition to other gases ${ }^{2}$ The type of gases generated from the radiolytic decomposition of organic materials depends upon the organic material involved. For a given type of material, the gas generation rate from radiolytic decomposition is directly proportional to the amount of energy deposited in the material. If plutonium is in direct contact with organic material, the energy is deposited in the form of both alpha particles and gamma radiation. If plutonium is contained in a metal container, the alpha particles are stopped by the metal, but some of the gamma radiation can penetrate the metal container. In this case, some of the gamma radiation energy will be deposited in the plastic packaging materials surrounding the metal can. The plutonium in the residue drum backlog is a mixture of plutonium isotopes, with one of the isotopes being ${ }^{241} \mathrm{Pu}$. The ${ }^{241} \mathrm{Pu}$ decays to ${ }^{241} \mathrm{Am}$ which is approximately 50 times as active as ${ }^{239} \mathrm{Pu}(3.47$ $\mathrm{Ci} / \mathrm{g}$ vs $0.0629 \mathrm{Ci} / \mathrm{g}$, respectively). Therefore, as the ${ }^{241} \mathrm{Pu}$ decays to ${ }^{241} \mathrm{Am}$, the energy released per gram of plutonium increases, and the gas generation rate increases as the plutonium in the residue drum backlog ages. Other factors affect the radiolytic gas generation rate, such as the particle size of the plutonium and the distribution of plutonium in the residue matrix. The americium content of most of the drums in the residue drum backlog is not known, and the plutonium 
particle size and distribution also are not known. Because of this lack of information, prediction of the radiolytic gas generation rate for any particular drum is difficult. However, identification of IDC categories which are likely to have high gas generation rates is possible, based upon existing experimental data.

Acid-metal reactions, such as reaction of nitric acid with mild steel drums, produce hydrogen and corrosion of the mild steel. Another source for gas generation is bacterial action. Carbon dioxide is the primary gas expected to be produced from bacterial action. ${ }^{1}$ Reactive metals, such as sodium, potassium, calcium, and magnesium, react with water to produce hydrogen.

Residue drums containing high organic material and/or liquid content produce the largest quantities of gas. Drums with a high gas generation rate have the highest potential for pressurization, either of the drum or packages in the drum, and for accumulation of hydrogen in the drum. Wet and dry combustibles, plastic, and drybox gloves are residue categories that can have high gas generation rates. Since all residue drums contain plastic packaging material, some residues that normally would not be considered to have a high gas generation potential may fit into this risk category. An example of this type of residue is drums of molten salt extraction (MSE) salts with high plutonium and americium contents.

\section{Contamination Containment Loss}

Contamination containment loss results from several different mechanisms. Plastic packaging materials are degraded by heat and radiation, and the degradation process is accelerated if both heat and radiation are present. PVC exposure to radiation results in dehydrochlorination, with the evolution of hydrogen chloride $(\mathrm{HCl})$. Heating PVC in air results in thermal oxidation and loss of strength, and the rate of degradation increases rapidly with increasing temperature. ${ }^{3}$ Radiation, heat, and nitric and hydrochloric acid vapors can degrade the adhesive on the yellow tape used to seal plastic bags, which can result in seal loss. Polyethylene bottles are affected by temperature and internal pressure. In tests conducted at Hanford, high density polyethylene bottles containing a 10 weight percent Igepal CD 630 solution failed after 40 hours at $50^{\circ} \mathrm{C}$ and 25 psig, where as bottle failure did not occur until after 2516 hours when the pressure was decreased to 15 psig. ${ }^{4}$ Drums with high plutonium and/or americium loadings produce high radiation fields, elevated temperatures, and elevated pressures in sealed containers as a result of gas generation from radiolysis of water and organic materials.

Contamination containment loss would be a problem primarily when a sealed drum was opened. However, vented drums containing acids or organic solvents may have carbon filter vent assembly corrosion because of attack on the vent assembly components by the acid vapors. If contamination containment were lost in the drum contents and in the vent assembly, contamination could be released from the drum.

The conditions resulting in contamination containment loss are most likely to occur in residue drums with high plutonium and/or americium loadings or with a high acid or chlorinated solvent content. MSE salts, Ful-Flo filters, and wet combustibles are examples of residue with a high probability of contamination containment loss.

\section{Drum and Residue Packaging Corrosion}

Residues containing high concentrations of nitric acid or chlorinated solvents are most likely to cause drum corrosion problems. The corrosion problems include corrosion of the drum itself, corrosion of the carbon filter assembly used for drum venting, or degradation of the drum gasket. Drums containing residues with a high acid content can become corroded as the acid vapors are released from the residues and react with the inner surfaces of the drum and drum lid. A recently opened drum (which had been in storage 
since 1986) containing ion exchange resin exhibited this type of corrosion. Approximately $75 \%$ of the drum lid was covered with "flaking rust," and the drum body inner surfaces were heavily corroded. ${ }^{5}$ Some attack on the foam gasket was also noted. Other residue categories, such as Ful-Flo filters fiom Building 771 operations, would be expected to contain much higher concentrations of nitric acid than the concentrations in the resin. The corrosion of Ful-Flo filter drums could be much worse over time than the corrosion found in the resin drum.

Corrosion can also occur in residue drums containing carbon tetrachloride (CCl4). Materials and Surface Technologies (MST) personnel have investigated corrosion problems with vent filters in drums used to store Ful-Flo filters that were used to filter $\mathrm{CCl} 4$ and oil mixtures. ${ }^{6}$ These corrosion problems are associated with $\mathrm{CCl} 4$ hydrolysis and radiolysis products. These hydrolysis and radiolysis products are known to attack the RTV silicone sealant used to hold the carbon filter plug in the filter housing and the carbon steel or stainless steel housings. An inspection of drums stored in Building 371 by MST personnel revealed corroded vent filters on approximately twenty drums. ${ }^{6}$ A more recent inspection of drums containing combustible residues identified 23 drums with corroded vent filters. ${ }^{7}$

Ful-Flo filters and wet combustibles are examples of residue that could contain high concentrations of nitric acid or chlorinated solvents. Ful-Flo filters or wet combustibles from Buildings 771 or 371 have a high probability of containing nitric acid. Ful-Flo filters from Building 707 have a high probability of containing chlorinated solvents in the form of $\mathrm{CCl} 4$ or other chlorinated solvents.

Residue packaging materials corrosion can occur if the residue is not compatible with the packaging material. Table 1 information shows that a number of pyrochemical salts are stored in stainless steel or tin plated steel cans. Because pyrochemical salts are chloride salts which tend to be hygroscopic, they become corrosive to stainless steel or tin plated steel when they become wet. Gibson and direct oxide reduction (DOR) salts are examples of pyrochemical salts that could become corrosive to stainless steel or tin plated steel cans.

\section{Reactive Metals and Compounds}

Reactive metals and compounds are primarily associated with certain types of pyrochemical salts. Sand, slag, and crucible (SS\&C) and DOR salts contain free calcium metal and may contain small pieces of plutonium metal. Radiographs taken of slags produced from reductions with varying metal yields show that small quantities of plutonium metal are present even in the slags from high metal yield reductions. ${ }^{8}$ The salts from low yield DOR runs may also contain. plutonium metal. Calcium metal reacts with water to produce calcium hydroxide $[\mathrm{Ca}(\mathrm{OH}) 2]$ and hydrogen gas. Plutonium metal reacts with water to produce plutonium hydride or plutonium oxide hydride, which are more pyrophoric than the metal.9,10 Older MSE salts contain free magnesium metal which reacts with water to form magnesium hydroxide $[\mathrm{Mg}(\mathrm{OH}) 2]$ and hydrogen gas. Some electrorefining (ER) salts may contain finely divided sodium metal which may be oxidized to sodium peroxide (Na2O2). Sodium peroxide is a powerful oxidizing agent, and $\mathrm{Na} 2 \mathrm{O} 2$ can react violently with some metals."

While reactive metals and compounds are primarily associated with pyrochemical salts, at least one non-pyrochemical salt residue may contain reactive compounds. Studies conducted at Rocky Flats have shown that a highly flammable and shock-sensitive material is formed when leaded drybox gloves are exposed to strong nitric acid. ${ }^{12,13}$ The yellowish material formed when nitric acid reacts with the lead oxide loaded glove layer is not a hazard as long as it is wet, but the material becomes very reactive when dried. This yellowish material was identified as a 
mixture of carboxylic acids containing nitro groups and lead nitrate. Many gloves in this IDC category (IDC 341) were coated with nitric acid when they were removed from the glovebox. The nitric acid could be degrading the packaging materials, and the flammable, shocksensitive material could be present on some of these gloves. If the gloves are stored in contact with nitric acid, the reactions which produce the flammable, shock-sensitive material could be occurring in the drums. Since all the residue drums containing acid contaminated drybox gloves should now be equipped with vent filters, the gloves could dry if they are stored for a sufficient period of time.

\section{RESIDUE IDC RISK RANKINGS}

The risk factors defined and discussed in the Risk Factors section were used to rank the various residue IDC categories by potential risk. Each residue IDC was evaluated to determine which of the risk factors might be associated with that particular IDC. The IDC categories were then assigned a risk potential, based upon the number of risk factors associated with the IDC and an estimate of the magnitude of the risk associated with each risk factor for the IDC. Risk potentials of one to five were used for ranking the IDC categories, with one being the highest risk potential and five being the lowest. IDC categories for which no risk factors were assigned were given a risk potential of five. The assignment of risk potentials was necessarily subjective, based upon the author's knowledge of and experience with the type of residue in each of the IDC categories. However, the purpose of this risk ranking was to provide a priority list for obtaining additional information on the true condition of the residues in the drum backlog. The IDC categories with the highest risk rankings are the categories which should be investigated first in any program designed to obtain additional information on the current condition of the residues in the drum backlog.

A listing of the residue IDC categories currently stored in 55-gallon drums in the drum backlog is given in Table 2. This table lists the IDC number, the IDC description, the number of residue drums, the risk factors associated with the IDC, and the risk potential assigned to the IDC. The IDCs within each risk potential category are sorted in ascending order by IDC number; the order in which the IDCs are listed within a risk potential category is not significant. For example, IDC 290 (Filter Sludge) is the first IDC listed with a risk potential of two, and IDC 431 (Leached Resin) is the last IDC listed in this risk category. However, the table order does not imply that filter sludge is thought to pose a higher risk than ion exchange resin. Sorting IDCs into risk potential categories was difficult because of the lack of data on the actual condition of residues in the drum backlog. Sorting IDCs within a risk potential category will not be possible until additional data are obtained.

As was stated previously, assignment of a risk potential to the various IDC categories was somewhat subjective; however, all IDC categories with a risk potential of one were assigned that risk potential for specific reasons. The one drum of IDC 050 (Skulls) is a good example. Skulls are a mixture of oxide, sub-oxide, and metal produced in a casting operation; they are very pyrophoric. The possibility exists that the drum has been misidentified and the material in the drum is not really skulls. The drum is listed in SAN with a net weight of 7100 grams and a plutonium weight of 239 grams. The plutonium assay implied by these weights is much too low for casting skulls. However, if the drum, number D7430916, really does contain casting skulls, the drum should be opened as soon as possible and the material placed into a safe storage configuration. This drum has been identified as one of the containers to be opened and inspected during Phase 1 of the HSP 31.11 Inspection Plan program. $^{14}$

The drums of IDC 061 (Non-Spec Oxide) and IDC 080 (Peroxide Cake) were given a risk potential of one because a 55-gallon drum is not 
Table 2

RISK POTENTIAL RANKING FOR RESIDUE BACKLOG IDC CATEGORIES

\begin{tabular}{|c|c|c|c|c|}
\hline IDC & DESCRIPTION & $\begin{array}{l}\text { No. } \\
\text { DRUMS }\end{array}$ & $\begin{array}{l}\text { RISK } \\
\text { FACTORS }\end{array}$ & $\begin{array}{l}\text { RISK } \\
\text { POTENTIAL }\end{array}$ \\
\hline 050 & SKULLS & 1 & 2,4 & 1 \\
\hline 061 & NON-SPEC OXIDE & 2 & 2 & 1 \\
\hline 080 & PEROXIDE CAKE & 1 & 1,2 & 1 \\
\hline 331 & FILTERS, FUL-FLO, NOT.FROM INCINERATOR & 188 & $1,2,3$ & 1 \\
\hline 336 & COMBUSTIBLIES, WET & 324 & $1,2,3$ & 1 \\
\hline 341 & LEADED GLOVES, ACID CONTAMINATED (1) & 25 & $1,2,3$ & 1 \\
\hline 363 & ELECTROREFINING SALT, FIRST USE & 1 & $1,2,3,4$ & 1 \\
\hline 364 & ELECTROREFINING SALT, SECOND USE & 1 & $1,2,3,4$ & 1 \\
\hline 405 & MOLTEN SALT UNKNOWN $\%$ UNPULVERIZED & 29 & 1,$2 ; 3,4$ & 1 \\
\hline 407 & MOLTEN SALT $8 \%$ UNPULVERIZED & 19 & $1,2,3,4$ & 1 \\
\hline 409 & MOLTEN SALT $30 \%$ UNPULVERIZED & 272 & $1,2,3,4$ & 1 \\
\hline 411 & ELECTROREFINING SALT FINAL DISPOSITION & 170 & $1,2,3,4$ & 1 \\
\hline 412 & GIBSON SALT & 3 & $1,2,3,4$ & 1 \\
\hline 413 & IMPURE SALT FROM CELL CLEANOUT & 33 & $1,2,3,4$ & 1 \\
\hline 414 & DOR SALT, UNOXIDIZED Ca & 30 & $1,2,3,4$ & 1 \\
\hline 415 & PLUTONIUM C:HLORIDE MIXED SALT & 10 & $1,2,3,4$ & 1 \\
\hline 473 & ER SALT PACKAGED FOR LANL & 11 & $1,2,3,4$ & 1 \\
\hline 654 & ER SALT FROM Pu/NP & 1 & $1,2,3,4$ & 1 \\
\hline
\end{tabular}

(1) INCLUDES SOME DRUMS MARKED AS WASTE IN WEMS 
Table 2 (Continued)

RISK POTENTIAL RANKING FOR RESIDUE BACKLOG IDC CATEGORIES

\begin{tabular}{|c|c|c|c|c|}
\hline IDC & DESCRIPTION & $\begin{array}{l}\text { No. } \\
\text { DRUMS }\end{array}$ & $\begin{array}{l}\text { RISK } \\
\text { FACTORS } \\
\end{array}$ & $\begin{array}{l}\text { RISK } \\
\text { POTENTIAL }\end{array}$ \\
\hline 290 & FILTER SLUDGE & 36 & 1,3 & 2 \\
\hline 292 & INCINERATOR SLUDGE (1) & 70 & 1,3 & 2 \\
\hline 299 & MISCELLANEOUS SLUDGE & 8 & 1,3 & 2 \\
\hline 310 & GRAPHITE SCARFINGS AND FINES & 85 & 2,4 & 2 \\
\hline 330 & COMBUSTIBLES, DRY & 191 & 1 & 2 \\
\hline 332 & OILY SLUDGE & 1 & 1,3 & 2 \\
\hline 333 & CALCIUM METAL & 2 & $1,2,4$ & 2 \\
\hline 337 & PLASTIC & 61 & 1 & 2 \\
\hline 339 & LEADED GLOVES, NOT ACID CONTAMINATED (1) & 4 & 1 & 2 \\
\hline 340 & SLUDGE FROM SIZE REDUCTION AREA & 9 & 1,3 & 2 \\
\hline 342 & DRYBOX FILTERS, ACID CONTAMINATED & 34 & 2,3 & 2 \\
\hline 404 & MOLTEN SALT, $\mathrm{Ca}, \mathrm{Zn}, \mathrm{K}$ & 4 & 2,4 & 2 \\
\hline 408 & MOLTEN SALT $8 \%$ PULVERZED & 6 & 2,3 & 2 \\
\hline 410 & MOLTEN SALT $30 \%$ PULVERIZED & 7 & 2,3 & 2 \\
\hline 419 & UNPULVERIZED INCINERATOR ASH & 3 & 1 & 2 \\
\hline 420 & PULVERIZED INCINERATOR ASH & 785 & 1 & 2 \\
\hline 428 & ASH SELECTED FOR MMEC & 3 & 1 & 2 \\
\hline 431 & RESI, LEACHED & 14 & 1,3 & 2 \\
\hline
\end{tabular}

(1) INCLUDES SOME DRUMS MARKED AS WASTE IN WEMS 
Table 2 (Continued)

RISK POTENTIAL RANKING FOR RESIDUE BACKLOG IDC CATEGORIES

\begin{tabular}{|l|l|l|l|l|}
\hline IDC & & $\begin{array}{l}\text { NO } \\
\text { DRUMS }\end{array}$ & $\begin{array}{l}\text { RISK } \\
\text { FACTORS }\end{array}$ & $\begin{array}{l}\text { RIKK } \\
\text { POTENTIAL }\end{array}$ \\
\hline 338 & FLLTER MEDIA & 205 & 3 & 3 \\
\hline 365 & SALT FROM BAD DOR RUN & 1 & 2,4 & 3 \\
\hline 370 & LECO CRUCIBLE & 161 & 1,2 & 3 \\
\hline 390 & UNPULVERIZED SLAG & 4 & 2,4 & 3 \\
\hline 391 & UNPULVERIZED SAND AND CRUCIBLE & 28 & 2,4 & 3 \\
\hline 392 & UNPULVERIZED SAND, SLAG AND CRUCIBLE & 64 & 2,4 & 3 \\
\hline 394 & SAND FROM BUTTON BREAKOUT (BBO) & 9 & 2,4 & 3 \\
\hline 398 & PULVERIZED SS\&C & 29 & 2 & 3 \\
\hline 422 & SOOT & 18 & 1 & 3 \\
\hline 427 & MSE SPENT DICESIUM SALT & 4 & 2 & 3 \\
\hline 429 & SCRUB ALLOY SPENT SALT & 44 & 2,4 & 3 \\
\hline 434 & FREE CALCIUM CONTAINING SPENT SALT & 1 & 4 & 3 \\
\hline 312 & GRAPHITE, COARSE & 121 & 4 & 4 \\
\hline 368 & MgOCRUCIBLES, NOT LECO & 66 & 2,4 & 4 \\
\hline 376 & PROCESSED FILTER MEDIA & 33 & 3 & 4 \\
\hline 421 & ASH HEEL & 328 & 3 & 4 \\
\hline 426 & REBURNED DC 413 & 2 & 2 & 4 \\
\hline 433 & SCRUB ALLOY SPENT DICESIUM SALT & 3 & 4 & 4 \\
\hline 655 & ER CERAMICS FROM PUNP & 3 & 4 & 4 \\
\hline
\end{tabular}


Table 2 (Continued)

RISK POTENTIAL RANKING FOR RESIDUE BACKLOG IDC CATEGORIES

\begin{tabular}{|c|c|c|c|c|}
\hline IDC & DESCRIPTION & $\begin{array}{l}\text { NO. } \\
\text { DRUMS }\end{array}$ & $\begin{array}{l}\text { RISK } \\
\text { FACTORS } \\
\end{array}$ & $\begin{array}{l}\text { RISK } \\
\text { POTENTIAL } \\
\end{array}$ \\
\hline 025 & AL ALLOY ANODE HEEL FOR SRP & 1 & & 5 \\
\hline 200 & STANDARDS & 6 & & 5 \\
\hline 300 & GRAPHTE MOLDS & 126 & & 5 \\
\hline 301 & CLASSIFIED GRAPHITE SHAPES & 83 & & 5 \\
\hline 303 & SCARFED GRAPHITE CHUNKS & 5 & & 5 \\
\hline 310 & GRAPHITE SCARFINGS AND FINES & 85 & & 5 \\
\hline 320 & HEAVY NON-SS METAL (Ta, W, Pi) & 50 & & 5 \\
\hline 334 & BLANKET, FIRE & 1 & & 5 \\
\hline 335 & DRYBOX FILTERS, NOT ACID CONTAMINATED & 23 & & 5 \\
\hline 360 & $\mathrm{Al}_{2} \mathrm{O}_{3}$ CERAMIC CRUCIBLES & 1 & & 5 \\
\hline 369 & LECO HEEL & 1 & & 5 \\
\hline 371 & FIREBRICK & 15 & & 5 \\
\hline 372 & GRIT & 2 & & 5 \\
\hline 373 & FIREBRICK HEEL & 4 & & 5 \\
\hline 377 & FIREBRICK, COARSE & 38 & & 5 \\
\hline 378 & FIREBRICK, PULVERZED OR FINES & 4 & & 5 \\
\hline 393 & SAND, SLAG AND CRUCIBLE HEEL & 19 & & 5 \\
\hline 438 & INSULATION & 8 & & 5 \\
\hline 440 & GLASS (EXCEPT RASCHIG RINGS) & 43 & & 5 \\
\hline 441 & UNLEACHED RASCHIG RINGS & 5 & & 5 \\
\hline 442 & LEACHED RASCHIG RINGS & 13 & & 5 \\
\hline 480 & LIGHT METAL & 122 & & 5 \\
\hline 490 & HEPA FILTERS (24X24), NOT ACID CONTAMINATED & 4 & & 5 \\
\hline
\end{tabular}


a good storage container for plutonium oxide. Under certain conditions, inner storage container pressurization and contamination containment loss are a possibility with plutonium oxide. Material dispersion risk that could result from the contamination containment loss is very high. However, the possibility exists that this material has been misidentified. All three of the drums listed in SAN as containing oxide are mixed IDC drums.

Drum number D21541 is listed as IDC 044 (Am and Misc Oxide), but the drum contains 10 cans identified as IDC 061. However, these 10 cans contain 10 grams of plutonium and 63 grams of americium. Drum number D48815 is listed as IDC 413 (Impure Salt from Cell Cleanout) but the listing of individual cans shows two cans of IDC 413, one can of IDC 061, four cans of IDC 411 , six cans of IDC 414, five cans of IDC 407, one can of IDC 368, one can of IDC 320, and one can of IDC 417. Drum number D25921 is listed as an IDC 420 (Incinerator Ash) drum, but the listing for individual cans shows three cans of ash and one can of IDC 080. These drums should also be opened, the contents verified, and the oxide placed in a safe storage configuration.

IDCs 331 and 336 were assigned a risk potential of one for several reasons. The residue in both of these IDC categories, Ful-Flo filters and wet combustibles, is known to have high hydrogen generation rates, and spontaneous combustion has occurred in drums of wet combustibles in the past. Drum-vent filter corrosion problems have already been identified with some drums containing Ful-Flo filters. ${ }^{6}$

The ER salt IDCs $(363,364,411,473$ and 654) were assigned a risk potential of one because of the potential for sodium peroxide formation and the very high plutonium loading in some of the drums. ${ }^{11}$ The unpulverized MSE salt IDCs (405, 407 and 409) were assigned a risk potential of one because of the potential for hydrogen formation, the potential for corrosion of the metal cans used to package the salt, and the high plutonium loading in some of the drums. The other pyrochemical salt IDCs $(412,413,414$ and 415) were assigned a risk potential of one for reasons similar to the reasons for assigning a risk potential of one to the MSE salt IDCs.

IDC 341 (Leaded Gloves, Acid Contaminated) was assigned a risk potential of one because of the potential presence of unstable compounds. ${ }^{12.13}$ As stated previously, the yellowish material which can form when leaded gloves are exposed to nitric acid is highly flammable and shock sensitive when dried.

Some of the IDCs which were assigned similar risk factors were assigned different risk potentials based upon an assessment of the difference in the magnitude of the risk factors for the different IDCs. For example, IDC 337 (Plastic) and IDC 422 (Soot) were both assigned risk factor one, gas generation. However, IDC 337 was assigned a risk potential of two, and IDC 422 was assigned a risk potential of three. The reason the IDCs were assigned different risk potentials was that while both plastic and soot have the potential for gas generation, the gas generation rate from plastic is greater than the gas generation rate expected from soot. ${ }^{1}$

The statement was made previously in this report that this study was limited to residue drums. However, some waste drums were included in the data used to develop the numbers given in Table 2 for three IDC categories, 339 (Leaded Gloves, Not Acid Contaminated), 341 (Leaded Gloves, Acid Contaminated) and 292 (Incinerator Sludge). The residue drum database contains only one drum each in the IDC 339 and 292 categories and eight drums in the IDC 341 category. Some waste drums in these IDC categories were added to the data used for this study because even low plutonium content drums in these IDC categories can contain significant quantities of hydrogen. A gas sampling study conducted at the Idaho National Engineering Laboratory (INEL) showed that a six-month old IDC 292 drum with 69 grams of 
plutonium contained 9.08 percent hydrogen, and a three-year old IDC 292 drum with 62 grams of plutonium contained 23.2 percent hydrogen. . $^{15,16}$ In the same study, a 12-year old IDC 339 drum that contained only three grams of plutonium was found to contain 4.12 percent hydrogen. These results show that in some IDC categories, even low plutonium content drums can contain greater than lower flammability limit quantities of hydrogen.

\section{DISCUSSION}

The major difficulty encountered in attempting to assess the potential safety risks in the residue drum backlog is the lack of data on the actual conditions that currently exist in the drums stored in the backlog. Experimental data do exist for the gas generation rates for a few of the IDC categories, but gas generation rate information is not available for most of the IDC categories. A similar lack of data exists for the other risk factors defined in this report. Another problem is lack of documentation for packaging configurations that actually exist in the drums stored in the residue drum backlog. A central location for data on the current condition of the drums in the residue drum backlog is needed. The WEMS database currently contains information on drums in the drum backlog, and upgrading WEMS to include information on the condition of backlog residue drums might be possible.

\section{Gas Generation}

The INEL gas sampling study referred to previously was conducted on waste drums generated in the 1970 s and early 1980 s. $^{15,16}$ Study results showed that drums in several IDC categories contained high hydrogen concentrations. One drum of dry combustibles, IDC 330 , contained 18.2 percent hydrogen. This drum, number 7602898, was generated on September 24, 1982 , and contained 29 grams of plutonium. The gas sample was taken six months after the drum was generated. Two 12-year old IDC 330 drums that were sampled contained hydrogen concentra- tions of 7.33 and 13.6 percent. Six-month old drums of cemented resins were found to contain hydrogen concentrations as high as 11.7 percent, and 12-year old drums of cemented resin were found to contain hydrogen concentrations as high as 27.1 percent.

One solution to the problem of gas generation in residue drums has been to equip the drums with permeable, foam, drum-lid gaskets or drum lids containing vent filters. However, these gaskets or filters may not totally solve the gas generation and hydrogen buildup problems in some of the residue categories. Computer modeling studies have been conducted to investigate possible gas compositions in residue drums to determine if computer models could be developed to predict gas compositions in residue drums.

Gas generation rate data for anion exchange resin and a few other materials were determined in a study conducted at Rocky Flats. ${ }^{2}$ The data were used to calculate the expected gas composition in the backlog resin drums that contain the highest plutonium concentrations. These calculations were performed assuming that the drums are sealed and that all gases generated remain in the drums. This assumption is known to be false, because some of the hydrogen and other gases generated in the drums diffuses through the drum-lid gaskets. However, the calculations served as a starting point in developing models that might be useful in predicting gas compositions in residue drums. The results of these first calculations, given in Table 3, show that resin drums could contain as much as 15 volume percent hydrogen if all of the gas generated remained in the drum.

The next step in the model development effort was to obtain actual gas samples from some of the resin drums and compare the actual gas compositions with the calculated compositions. The analyzed and calculated gas compositions for the first two drums that were sampled are shown in Table 4. As expected, the actual hydrogen content in the drums was much lower 
Table 3

CALCULATED GAS COMPOSITION IN SELECTED, SEALED RESIN DRUMS (IDC 431)

\begin{tabular}{|c|c|c|c|c|c|c|c|c|c|}
\hline \multirow{2}{*}{$\begin{array}{l}\text { DRUM } \\
\text { NUMBER }\end{array}$} & \multirow{2}{*}{$\begin{array}{l}\text { Pu } \\
\text { WEIGHT, } \\
\text { GRAMS }\end{array}$} & \multirow{2}{*}{$\begin{array}{l}\text { DATE } \\
\text { CREATED }\end{array}$} & \multirow{2}{*}{$\begin{array}{l}\text { YEARS } \\
\text { STORED }\end{array}$} & \multirow{2}{*}{$\begin{array}{l}\text { CALCULATED } \\
\text { PRESSURE, Im } \\
\text { Hg } \\
\text { (2) }\end{array}$} & \multicolumn{2}{|c|}{ COMPOSITION OF GASSES } & \multicolumn{3}{|c|}{ IN DRUM, VOLUME PERCENT } \\
\hline & & & & & $\mathbf{N}_{2}$ & $\mathrm{O}_{2}$ & $\mathrm{H}_{2}$ & $\mathrm{Co}$ & $\mathrm{CO}_{2}$ \\
\hline 33245 & 267 & $8 / 18 / 83$ & 10 & 660 & 73.39 & 0.00 & 15.64 & 1.56 & 9.41 \\
\hline 31686 & 198 & $\begin{array}{c}1986 \\
(1) \\
\end{array}$ & 7 & 579 & 83.59 & 0.00 & 9.64 & 0.96 & 5.81 \\
\hline 31790 & 193 & $\begin{array}{c}1987 \\
(1) \\
\end{array}$ & 6 & 563 & 85.98 & 0.00 & 8.23 & 0.82 & 4.97 \\
\hline 52400 & 82 & $7 / 22 / 86$ & 7 & 521 & 92.90 & 0.00 & 4.16 & 0.42 & 2.52 \\
\hline 51836 & 68 & $6 / 05 / 86$ & 7 & 532 & 90.95 & 3.13 & 3.47 & 0.35 & 2.11 \\
\hline 53719 & 12 & $2 / 04 / 86$ & 7.5 & 601 & 80.50 & 18.64 & 0.49 & 0.05 & 0.32 \\
\hline
\end{tabular}

(1) Exact generation date is unknown.

(2) Atmospheric pressure at the Rocky Flats Plant is approximately $610 \mathrm{~mm} \mathrm{Hg}$. 
Table 4

Calculated and Actual Gas Composition and Drum Pressure For Resin Drums (IDC 431)

\begin{tabular}{|c|c|c|c|c|c|c|c|c|}
\hline \multirow[t]{2}{*}{ DRUM NO. } & \multirow{2}{*}{$\begin{array}{l}\text { TYPE OF } \\
\text { RESULT }\end{array}$} & \multicolumn{6}{|c|}{ GAS COMPOSITION, VOLUME PERCENT } & \multirow{2}{*}{$\begin{array}{l}\text { DRUM } \\
\text { PRES- } \\
\text { SURE, mm } \\
\text { Hg (2) } \\
\end{array}$} \\
\hline & & $\mathrm{Co}$ & $\mathrm{N}_{2}$ & $\mathrm{CO}_{2}$ & Ar & $\mathrm{O}_{2}$ & $\mathrm{H}_{2}$ & \\
\hline \multirow[t]{2}{*}{53719} & CALCULATED & 0.05 & 80.50 & 0.32 & $\mathrm{~N} / \mathrm{C} \quad(1)$ & 17.64 & 0.49 & 601 \\
\hline & MEASURED & 0.057 & 79.70 & 0.64 & 0.94 & 18.61 & 0.0522 & 604 \\
\hline \multirow[t]{2}{*}{51836} & CALCULATED & 0.35 & 90.95 & 3.13 & $\mathrm{~N} / \mathrm{C} \quad(1)$ & 3.13 & 3.47 & 532 \\
\hline & MEASURED & 0.0776 & 77.70 & 4.07 & 0.925 & 16.72 & 0.47 & 612 \\
\hline
\end{tabular}

(1) N/C-Not calculated

(2) Atmospheric pressure at the Rocky Flats Plant is approximately $610 \mathrm{~mm} \mathrm{Hg}$. 
than the calculated hydrogen content. The difference in the actual and calculated hydrogen contents in these two drums was used to calculate gas permeability constants for the foam gaskets used on the drums. These gas permeability constants were then used to recalculate the expected gas compositions in the high plutonium content resin drums that had not yet been sampled. Three more of the high plutonium content resin drums have now been sampled. The recalculated gas compositions are given in Table 5, along with the measured gas compositions. The gas permeability constants used to recalculate the expected gas compositions are also given in Table 5.

A comparison of the recalculated and measured gas compositions in Table 5 shows that the measured hydrogen concentration in the drums was still less than the recalculated compositions. The resin drum gas sampling results show that the rate of hydrogen permeation through the foam, drum-lid gasket is sufficient to maintain the hydrogen concentration in the resin drums below the lower flammability limit for hydrogen.

The gas sampling results indicate that hydrogen build up in resin drums should not be a problem if the drums are equipped with foam gaskets. However, the experimentally determined hydrogen generation rate for resin is only $14 \mathrm{ml} / \mathrm{yr} / \mathrm{g}$ $\mathrm{Pu}^{2}$ The experimentally determined hydrogen generation rate for dry combustibles, IDC 330, is $180 \mathrm{ml} / \mathrm{yr} / \mathrm{g} \mathrm{Pu}$, or an order of magnitude greater than the hydrogen generation rate for resin. ${ }^{1}$ The possibility exists that the hydrogen generation rate for some residues would be so great that hydrogen build up could occur even if the foam gaskets are functioning properly. The possibility also exists that some of the drums in the residue drum backlog may not be equipped with either foam, drum-lid gaskets or drum-vent filter assemblies.

The Rocky Flats Plant Standard for drum-lid gaskets, SX-205, did not require foam gasket use until November 1982. Prior to November 1982 , the plant standard called for a tubular, styrenebutadiene gasket. These tubular gaskets have much lower gas permeation rates than do foam gaskets. The drum gasket standard was revised again in June 1986 to allow use of either foam or tubular gaskets. The Rocky Flats Plant Standard for carbon composite drum-vent filter assemblies, SX-233, was not issued until January 1988. Therefore, drums generated prior to 1983 or between 1986 and 1988 could be equipped with tubular gaskets.

A visual inspection was recently conducted of all residue drums in certain IDC categories known to have high gas generation rates. The purpose of this visual inspection was to ensure that all drums of residues in IDC categories $330,331,336,337,338$, 339 and 341 are fitted with drum-vent filter assemblies. This inspection confirmed that all IDC 331 residue drums are equipped with drum-vent filter assemblies. However, the inspection revealed that 19 drums in IDC categories $330,336,337,338$, 339 , and 341 were not equipped with drum-vent filter assemblies. A project was put in place to obtain gas samples from these 19 drums, vent the drums to remove any hydrogen in the drums, and replace the drum lids with lids containing carbon composite filter assemblies. ${ }^{17}$

As part of the gas sampling and lid replacement project, the operators performing the work were asked to determine the type of drum-lid gasket. The initial reports indicated that all 19 drums were fitted with solid gaskets. However, further investigation revealed that some of the gaskets may have been foam gaskets. A more detailed investigation of 17 of the 19 drum lids revealed that 14 lids are equipped with foam gaskets, and three lids are equipped with solid, tubular gaskets. Unfortunately, by the time the more detailed investigation was conducted, determining which lid had been removed from which drum was impossible. However, the fact that three drum lids are equipped with tubular gaskets confirms that some drums in the residue drum backlog are equipped with solid, tubular gaskets. 
Table 5

Recalculated and Actual Gas Composition and Drum Pressure For Resin Drums (IDC 431)

\begin{tabular}{|c|c|c|c|c|c|c|c|c|}
\hline \multirow[t]{2}{*}{ DRUM NO. } & \multirow{2}{*}{$\begin{array}{l}\text { TYPE OF } \\
\text { RESULT }\end{array}$} & \multicolumn{6}{|c|}{ GAS COMPOSITION, VOLUME PERCENT } & \multirow{2}{*}{$\begin{array}{l}\text { DRUM } \\
\text { PRES- } \\
\text { SURE, mm } \\
\text { Hg (1) }\end{array}$} \\
\hline & & $\mathrm{CO}$ & $\mathrm{N}_{2}$ & $\mathrm{CO}_{2}$ & Ar & $\mathrm{O}_{2}$ & $\mathrm{H}_{2}$ & \\
\hline \multirow[t]{2}{*}{31686} & $\begin{array}{c}\text { RECALCULATED } \\
\text { GAS } \\
\text { COMPOSITION }\end{array}$ & 0.39 & 85.00 & 11.93 & 1.02 & 0.53 & 1.13 & 569 \\
\hline & MEASURED & 0.02 & 77.80 & 0.32 & 0.96 & 20.84 & 0.06 & 614 \\
\hline \multirow[t]{2}{*}{31790} & $\begin{array}{c}\text { RECALCULATED } \\
\text { GAS } \\
\text { COMPOSITION }\end{array}$ & 0.38 & 84.81 & 11.60 & 1.02 & 1.09 & 1.10 & 570 \\
\hline & MEASURED & 0.03 & 77.70 & 1.00 & 0.96 & 20.21 & 0.08 & 614 \\
\hline \multirow[t]{2}{*}{52400} & $\begin{array}{c}\text { RECALCULATED } \\
\text { GAS } \\
\text { COMPOSITION }\end{array}$ & 0.15 & 80.78 & 4.70 & 0.97 & 12.95 & 0.44 & 599 \\
\hline & MEASURED & 0.04 & 77.39 & 1.05 & 0.96 & 20.47 & 0.09 & 607 \\
\hline
\end{tabular}

(1) Atmospheric pressure at the Rocky Flats Plant is approximately $610 \mathrm{~mm} \mathrm{Hg}$.

CALCULATED PERMEABILITY OF DRUM IID GASKETS

Permeability for Foam Gasket $(\mathrm{cm}, \mathrm{cc} / \mathrm{cm} . \mathrm{sq}, \mathrm{sec}, \mathrm{mm} \mathrm{Hg})$

HYDROGEN

OXYGEN

NITROGEN

CARBON DIOXIDE

CARBON MONOXIDE
1. $5 \mathrm{E}-07$

$4.7 \mathrm{E}-08$

4. $0 \mathrm{E}-07$

8. 7E-09

4. $4 \mathrm{E}-08$ 
Prior to the start of gas sampling operations on the 19 drums of combustible residues, calculations were performed to determine the expected and worst case hydrogen concentration in the 15 drums containing material for which gas generation rate information was available. The expected and worst case gas compositions were calculated, based upon gas generation rates determined previously at Rocky Flats on drums of actual waste and residue. ${ }^{1}$ The expected gas composition calculations were performed assuming that the drum lids were fitted with foam gaskets. Another assumption was that the equilibrium partial pressure of each individual gas in a drum would be the pressure at which the gas generation rate would equal the gas permeation rate through the drum gasket. The gas permeation rates used for these calculations were determined from the gas sampling operations conducted on drums of ion exchange resin which were all fitted with foam gaskets. Calculations for worst case hydrogen concentrations were performed assuming a sealed drum and that all of the hydrogen generated would remain in the drum.

The calculated expected and worst case gas compositions are shown in Tables 6 through 9, along with the measured gas compositions for the 15 drums containing material for which gas generation rate information was available. The worst case gas compositions are shown in these tables in the "Type of Result" column as "Calculated, No Loss". The expected gas compositions are shown in the "Type of Result" column as "Calculated, Foam Gasket." As expected, none of the measured hydrogen concentrations is even close to the worst case hydrogen concentrations. For the IDC 330 (Table 6) and IDC 337 (Table 8) drums, the measured hydrogen concentrations were much lower than the calculated, expected hydrogen concentrations.

For the IDC 336 (Table 7) drums, some of the measured hydrogen concentrations were much higher than the calculated, expected hydrogen concentrations. The best agreement between measured and calculated, expected hydrogen concentrations was obtained for IDC 339 and 341 (Table 9) drums. In most of the drums where the hydrogen concentration was higher than expected, the oxygen concentration was lower than expected. These concentrations are not surprising since the radiolysis reactions that generate hydrogen consume oxygen.

The wide variation between the expected and measured gas compositions can be explained by several factors: (1) the gas generation rate data used for calculating the expected gas compositions are based on measurements from only a few drums for each IDC category; (2) large variations in gas generation rates between drums in the same IDC category were observed during the gas generation rate experiments; (3) gas generation rates are dependent not only on the type of material and plutonium content, but upon the amount of plutonium in direct contact with the material being irradiated; and (4) a wide variation in gas permeation rates exists from gasket to gasket. Experiments were conducted at Rocky Flats to determine the gas permeation rates for samples of foam, drum gasket material. ${ }^{18}$ The measured gas permeation rates vary from $7 \times 10^{-6}$ to $1 \times 10^{-11}$ moles $/$ second/centimeter squared $\mathrm{x}$ torr for hydrogen and from $1 \times 10^{-7}$ to $1 \times 10^{-9}$ for oxygen.

Gas permeation rates were calculated for each of the 15 drums. The permeation rates were calculated based upon experimental gas generation rate data and the measured gas composition in the drums. ${ }^{1}$ The results of these calculations are given in Table 10, along with the average permeation rate calculated for the five ion exchange resin drum gaskets. As the results in Table 10 show, a wide variation in permeation rate is found from drum to drum.

The results from the gas sampling operation show why fitting drums of combustible material with vent filters is important. The one drum of IDC 341 material, D60056, which contained the largest quantity of plutonium, contained a hydrogen-oxygen mixture that was close to the flam- 
Table 6

Calculated and Actual Gas Composition and Drum Pressure for IDC 330 Drums

\begin{tabular}{|c|c|c|c|c|c|c|c|c|}
\hline \multirow{2}{*}{$\begin{array}{l}\text { DRUM NO } \\
\text { AND PU } \\
\text { CONTENT }\end{array}$} & \multirow{2}{*}{$\begin{array}{l}\text { TYPE OF } \\
\text { RESULT }\end{array}$} & \multicolumn{6}{|c|}{ GAS COMPOSITION, VOLUME PERCENT } & \multirow{2}{*}{$\begin{array}{c}\text { DRUM } \\
\text { PRESSURE, mm } \\
\text { Hg (1) } \\
\end{array}$} \\
\hline & & $\mathbf{N}_{2}$ & $\mathrm{O}_{2}$ & $\mathrm{H}_{2}$ & $\mathrm{CO}_{2}$ & $\mathrm{CO}$ & Ar & \\
\hline \multirow{3}{*}{$\begin{array}{l}57179 \\
61 \mathrm{~g} \mathrm{Pu} \\
\text { CREATED } \\
6 / 23 / 87\end{array}$} & $\begin{array}{c}\text { CALCULATED, } \\
\text { NO LOSS }\end{array}$ & 44.25 & 0.00 & 19.43 & 35.63 & 0.15 & 0.53 & 1087 \\
\hline & $\begin{array}{l}\text { CALCULATED, } \\
\text { FOAM GASKET }\end{array}$ & 72.94 & 13.86 & 0.53 & 11.77 & 0.02 & 0.88 & 663 \\
\hline & MEASURED & 78.10 & 20.80 & 0.015 & 0.195 & 0.011 & 0.938 & $605(606)$ \\
\hline \multirow{3}{*}{$\begin{array}{c}60320 \\
35 \mathrm{~g} \mathrm{Pu} \\
\text { CREATED } \\
2 / 2 / 88\end{array}$} & $\begin{array}{c}\text { CALCULATED, } \\
\text { NO LOSS }\end{array}$ & 60.78 & 0.00 & 13.55 & 24.84 & 0.11 & 0.73 & 790 \\
\hline & $\begin{array}{l}\text { CALCULATED, } \\
\text { FOAM GASKET }\end{array}$ & 75.03 & 16.79 & 0.31 & 6.95 & 0.01 & 0.90 & 644 \\
\hline & MEASURED & 78.10 & 20.80 & 0.013 & 0.161 & 0.012 & 0.932 & $605(610)$ \\
\hline
\end{tabular}

(1) ATMOSPHERIC PRESSURE AT TIME DRUM SAMPLED SHOWN IN PARENTHESIS 
Table 7

Calculated and Actual Gas Composition and Drum Pressure

for IDC 336 Drums

\begin{tabular}{|c|c|c|c|c|c|c|c|c|}
\hline \multirow{2}{*}{$\begin{array}{c}\text { DRUM NO } \\
\text { ANVE PU } \\
\text { CONTENT }\end{array}$} & \multirow{2}{*}{$\begin{array}{l}\text { TYPE OF } \\
\text { RESULT }\end{array}$} & \multicolumn{6}{|c|}{ GAS COMPOSITION, VOLUME PERCENT } & \multirow{2}{*}{$\begin{array}{c}\text { DRUM } \\
\text { PRESSURE, mm } \\
\text { Hg (1) }\end{array}$} \\
\hline & & $\mathrm{N}_{2}$ & $\mathrm{O}_{2}$ & $\mathrm{H}_{2}$ & $\mathrm{CO}_{2}$ & $\mathrm{CO}$ & Ar & \\
\hline \multirow{3}{*}{$\begin{array}{c}61278 \\
87 \mathrm{~g} \mathrm{Pu} \\
\text { CREATED } \\
3 / 29 / 88\end{array}$} & $\begin{array}{c}\text { CALCULATED, } \\
\text { NO LOSS }\end{array}$ & 70.65 & 0.00 & 20.79 & 7.41 & 0.30 & 0.85 & 679 \\
\hline & $\begin{array}{l}\text { CALCULATED, } \\
\text { FOAM GASKET }\end{array}$ & 81.39 & 15.19 & 0.46 & 1.96 & 0.02 & 0.98 & 594 \\
\hline & MEASURED & 79.80 & 10.00 & 1.436 & 7.3 & 0.099 & 0.953 & $604(606)$ \\
\hline \multirow{3}{*}{$\begin{array}{c}49880 \\
65 \mathrm{~g} \mathrm{Pu} \\
\text { CREATED } \\
12 / 18 / 85\end{array}$} & $\begin{array}{c}\text { CALCULATED, } \\
\text { NO LOSS }\end{array}$ & 69.78 & 0.00 & 21.43 & 7.64 & 0.31 & 0.84 & 687 \\
\hline & $\begin{array}{l}\text { CALCULATED, } \\
\text { FOAM GASKET }\end{array}$ & 80.52 & 16.71 & 0.34 & 1.45 & 0.02 & 0.97 & 600 \\
\hline & MEASURED & 78.10 & 20.70 & 0.019 & 0.189 & 0.021 & 0.930 & $611(612)$ \\
\hline \multirow{3}{*}{$\begin{array}{c}61245 \\
34 \mathrm{~g} \mathrm{Pu} \\
\text { CREATED } \\
3 / 28 / 88\end{array}$} & $\begin{array}{l}\text { CALCULATED, } \\
\text { NO LOSS }\end{array}$ & 85.49 & 0.00 & 9.83 & 3.50 & 0.14 & 1.03 & 559.84 \\
\hline & $\begin{array}{l}\text { CALCULATED, } \\
\text { FOAM GASKET }\end{array}$ & 79.32 & 18.79 & 0.17 & 0.75 & 0.01 & 0.96 & 610 \\
\hline & MEASURED & 86.70 & 1.50 & 1.282 & 9.273 & 0.150 & 1.047 & $605(610)$ \\
\hline
\end{tabular}

(1) ATMOSPHERIC PRESSURE AT TIME DRUM SAMPLED SHOWN IN PARENTHESIS 
Table 7 (Continued)

Calculated and Actual Gas Composition and Drum Pressure

for IDC 336 Drums

\begin{tabular}{|c|c|c|c|c|c|c|c|c|}
\hline \multirow{2}{*}{$\begin{array}{l}\text { DRUM NO } \\
\text { AND Pu } \\
\text { CONTENT } \\
\end{array}$} & \multirow{2}{*}{$\begin{array}{l}\text { TYPE OF } \\
\text { RESULT }\end{array}$} & \multicolumn{6}{|c|}{ GAS COMPOSITION, VOLUME PERCENT } & \multirow{2}{*}{$\begin{array}{r}\text { DRUM } \\
\text { PRESSURE， mm } \\
\text { Hg (1) } \\
\end{array}$} \\
\hline & & $\mathrm{N}_{2}$ & $\mathrm{O}_{2}$ & $\mathrm{H}_{2}$ & $\mathrm{CO}_{2}$ & $\mathrm{Co}$ & Ar & \\
\hline \multirow{3}{*}{$\begin{array}{c}57522 \\
31 \mathrm{~g} \mathrm{Pu} \\
\text { CREATED } \\
7 / 22 / 87\end{array}$} & $\begin{array}{l}\text { CALCULATED, } \\
\text { NO LOSS }\end{array}$ & 85.27 & 0.00 & 9.99 & 3.56 & 0.14 & 1.03 & 561 \\
\hline & $\begin{array}{l}\text { CALCULATED, } \\
\text { FOAM GASKET }\end{array}$ & 79.21 & 18.99 & 0.16 & 0.68 & 0.01 & 0.95 & 611 \\
\hline & MEASURED & 82.20 & 4.00 & 1.863 & 9.782 & 0.953 & 0.933 & $606(606)$ \\
\hline \multirow{3}{*}{$\begin{array}{l}38989 \\
27 \mathrm{~g} \mathrm{Pu} \\
\text { CREATED } \\
4 / 30 / 84\end{array}$} & $\begin{array}{c}\text { CALCULATED, } \\
\text { NO LOSS }\end{array}$ & 81.71 & 0.00 & 12.62 & 4.50 & 0.18 & 0.98 & 586 \\
\hline & $\begin{array}{l}\text { CALCULATED, } \\
\text { FOAM GASKET }\end{array}$ & 79.06 & 19.26 & 0.14 & 0.59 & 0.01 & 0.95 & 612 \\
\hline & MEASURED & 78.00 & 20.80 & 0.010 & 0.186 & 0.017 & 0.938 & $605(610)$ \\
\hline \multirow{3}{*}{$\begin{array}{r}61747 \\
19 \mathrm{~g} \mathrm{Pu} \\
\text { CREATED } \\
\text { 4/22/88 }\end{array}$} & $\begin{array}{l}\text { CALCULATED, } \\
\text { NO LOSS }\end{array}$ & 91.00 & 0.00 & 5.76 & 2.05 & 0.08 & 1.10 & 525.58 \\
\hline & $\begin{array}{l}\text { CALCULATED, } \\
\text { FOAM GASKET }\end{array}$ & 78.75 & 19.78 & 0.10 & 0.41 & 0.01 & 0.95 & 614 \\
\hline & MEASURED & 78.40 & 19.90 & 0.682 & 0.668 & 0.028 & 0.940 & $607 \quad(610)$ \\
\hline
\end{tabular}

(1) ATMOSPHERIC PRESSURE AT TIME DRUM SAMPLED SHOWN IN PARENTHESIS 
Table 8

Calculated and Actual Gas Composition and Drum Pressure

for IDC 337 Drums

\begin{tabular}{|c|c|c|c|c|c|c|c|c|}
\hline \multirow{2}{*}{$\begin{array}{l}\text { DRUM NO AND } \\
\text { Du CONTENT }\end{array}$} & \multirow{2}{*}{$\begin{array}{l}\text { TYPE OF } \\
\text { RESULT }\end{array}$} & \multicolumn{6}{|c|}{ GAS COMPOSITION, VOLUME PERCENT } & \multirow{2}{*}{$\begin{array}{l}\text { DRUM } \\
\text { PRESSURE, mm } \\
\text { Hg (1) }\end{array}$} \\
\hline & & $\mathrm{N}_{2}$ & $\mathrm{O}_{2}$ & $\mathrm{H}_{2}$ & $\mathrm{CO}_{2}$ & $\mathrm{CO}$ & Ar & \\
\hline 06339 & $\begin{array}{l}\text { CALCULATED, } \\
\text { NO LOSS }\end{array}$ & 19.21 & 0.00 & 29.54 & 50.71 & 0.31 & 0.23 & 2512 \\
\hline \multirow{2}{*}{$\begin{array}{c}188 \mathrm{~g} \mathrm{Pu} \\
\text { CREATED } \\
\text { CONVRT }(2)\end{array}$} & $\begin{array}{l}\text { CALCULATED, } \\
\text { FOAM GASKET }\end{array}$ & 71.51 & 1.81 & 1.18 & 24.59 & 0.05 & 0.86 & 676 \\
\hline & MEASURED & 78.30 & 18.90 & 0.170 & 1.481 & 0.142 & 0.935 & $600(606)$ \\
\hline \multirow[t]{3}{*}{56095} & $\begin{array}{c}\text { CALCULATED, } \\
\text { NO. LOSS }\end{array}$ & 59.05 & 0.00 & 14.76 & 25.33 & 0.16 & 0.71 & 428 \\
\hline & $\begin{array}{l}\text { CALCULATED, } \\
\text { FOAM GASKET }\end{array}$ & 76.30 & 15.89 & 0.32 & 6.56 & 0.01 & 0.92 & 634 \\
\hline & MEASURED & 78.40 & 20.70 & 0.002 & 0.023 & 0.002 & 0.889 & $610 \quad(610)$ \\
\hline
\end{tabular}

(1) ATMOSPHERIC PRESSURE AT TIME DRUM SAMPLED SHOWN IN PARENTHESIS

(2) DRUM CREATED PRIOR TO SAN 
Table 9

Calculated and Actual Gas Composition and Drum Pressure for IDC 339 and 341 Drums

\begin{tabular}{|c|c|c|c|c|c|c|c|c|c|}
\hline \multirow{2}{*}{$\begin{array}{l}\text { DRUM NO AND } \\
\text { PU CONTENT }\end{array}$} & \multirow{2}{*}{$\begin{array}{l}\text { TYPE OF } \\
\text { RESULT }\end{array}$} & \multicolumn{6}{|c|}{ GAS COMPOSITION, VOLUME PERCENT } & \multirow{2}{*}{\multicolumn{2}{|c|}{$\begin{array}{c}\text { DRUM } \\
\text { PRESSURE, } \mathrm{mm} \\
\mathrm{Hg}(1)\end{array}$}} \\
\hline & & $\mathbf{N}_{2}$ & $\mathrm{O}_{2}$ & $\mathrm{H}_{2}$ & $\mathrm{CO}_{2}$ & $\mathrm{CO}$ & Ar & & \\
\hline 60056 & $\begin{array}{c}\text { CALCULATED, } \\
\text { NO LOSS }\end{array}$ & 23.64 & 0.00 & 49.82 & 25.83 & 0.43 & 0.28 & & 2040 \\
\hline \multirow{2}{*}{$\begin{array}{c}439 \mathrm{~g} \mathrm{Pu} \\
\text { CREATED } \\
1 / 8 / 88\end{array}$} & $\begin{array}{l}\text { CALCULATED, } \\
\text { FOAM GASKET }\end{array}$ & 68.91 & 6.63 & 3.24 & 20.29 & 0.10 & 0.83 & & 702 \\
\hline & MEASURED & 76.80 & 3.60 & 4.757 & 12.213 & 0.378 & 0.892 & 612 & $(610)$ \\
\hline 35306 & $\begin{array}{c}\text { CALCULATED, } \\
\text { NO LOSS }\end{array}$ & 23.74 & 0.00 & 49.75 & 25.79 & 0.43 & 0.29 & & 2031 \\
\hline \multirow{2}{*}{$\begin{array}{l}211 \text { g Pu } \\
\text { CREATED } \\
11 / 11 / 83\end{array}$} & $\begin{array}{l}\text { CALCULATED, } \\
\text { FOAM GASKET }\end{array}$ & 73.37 & 13.65 & 1.66 & 10.38 & 0.05 & 0.88 & & 659 \\
\hline & MEASURED & 77.60 & 8.40 & 1.546 & 10.49 & 0.378 & 0.916 & 609 & $(610)$ \\
\hline 61504 & $\begin{array}{c}\text { CALCULATED, } \\
\text { NO LOSS }\end{array}$ & 43.02 & 0.00 & 36.97 & 19.17 & 0.32 & 0.52 & & 1118 \\
\hline \multirow{2}{*}{$\begin{array}{l}155 \mathrm{~g} \mathrm{Pu} \\
\text { CREATED } \\
4 / 12 / 88\end{array}$} & $\begin{array}{l}\text { CALCULATED, } \\
\text { FOAM GASKET }\end{array}$ & 74.55 & 15.52 & 1.24 & 7.75 & 0.04 & 0.90 & & 649 \\
\hline & MEASURED & 78.50 & 14.30 & 0.676 & 4.826 & 0.200 & 0.935 & 609 & $(610)$ \\
\hline
\end{tabular}

(1) ATMOSPHERIC PRESSURE AT TIME DRUM SAMPLED SHOWN IN PARENTHESIS 
Table 9 (Continued)

Calculated and Actual Gas Composition and Drum Pressure for IDC 339 and 341 Drums

\begin{tabular}{|c|c|c|c|c|c|c|c|c|}
\hline \multirow{2}{*}{$\begin{array}{l}\text { DRUM NO AND } \\
\text { P1 CONTENT }\end{array}$} & \multirow{2}{*}{$\begin{array}{l}\text { TYPE OF } \\
\text { RESULT }\end{array}$} & \multicolumn{6}{|c|}{ GAS COMPOSITION, VOLUME PERCENT } & \multirow{2}{*}{$\begin{array}{c}\text { DRUM } \\
\text { PRESSURE， mm } \\
\text { Hg (1) } \\
\end{array}$} \\
\hline & & $\mathrm{N}_{2}$ & $\mathrm{O}_{2}$ & $\mathrm{H}_{2}$ & $\mathrm{CO}_{2}$ & $\mathrm{co}$ & Ar & \\
\hline 59053 & $\begin{array}{c}\text { CALCULATED, } \\
\text { NO LOSS }\end{array}$ & 47.39 & 0.00 & 34.07 & 17.67 & 0.30 & 0.57 & 1014 \\
\hline \multirow{2}{*}{$\begin{array}{c}119 \mathrm{~g} \mathrm{Pu} \\
\text { CREATED } \\
10 / 30 / 87\end{array}$} & $\begin{array}{l}\text { CALCULATED, } \\
\text { FOAM GASKET }\end{array}$ & 75.34 & 16.75 & 0.96 & 6.01 & 0.03 & 0.91 & 642 \\
\hline & MEASURED & 77.60 & 20.60 & 0.047 & 0.709 & 0.024 & 0.974 & $602(610)$ \\
\hline \multirow[t]{2}{*}{47501} & $\begin{array}{c}\text { CALCULATED, } \\
\text { NO LOSS } \\
\end{array}$ & 56.89 & 0.00 & 27.78 & 14.40 & 0.24 & 0.69 & 844 \\
\hline & $\begin{array}{l}\text { CALCULATED, } \\
\text { FOAM GASKET }\end{array}$ & 76.68 & 18.86 & 0.48 & 3.03 & 0.02 & 0.92 & 631 \\
\hline $\begin{array}{c}\text { CREATED } \\
7 / 8 / 85\end{array}$ & MEASURED & 79.50 & 15.30 & 0.230 & 3.748 & 0.161 & 0.947 & $611(610)$ \\
\hline
\end{tabular}

(1) ATMOSPHERIC PRESSURE AT TIME DRUM SAMPLED SHOWN IN PARENTHESIS 
Table 10

Calculated Drum Gasket Permeation Rates

\begin{tabular}{|c|c|c|c|c|c|}
\hline \multirow[t]{2}{*}{ IDC } & \multirow[t]{2}{*}{ DRUM NO } & \multicolumn{4}{|c|}{$\begin{array}{l}\text { GASKET PERMEATION RATE, } \mathrm{cm}, \mathrm{cc} / \mathrm{cm} \text { sq, sec, } \\
\mathrm{mm} \mathrm{Hg}\end{array}$} \\
\hline & & $\mathrm{H}_{2}$ & $\mathrm{O}_{2}$ & $\mathrm{CO}_{2}$ & $\mathrm{CO}$ \\
\hline 431 & RESIN DRUMS & 1. $10 \mathrm{E}-06$ & 8. $30 \mathrm{E}-07$ & $9.10 E-08$ & $3.00 \mathrm{E}-07$ \\
\hline \multirow[t]{2}{*}{330} & D57179 & $4.27 E-05$ & $7.29 E-06$ & $6.02 E-06$ & $4.53 E-07$ \\
\hline & D60320 & $2.83 E-05$ & $4.20 E-06$ & $4.20 E-06$ & 2. $40 \mathrm{E}-07$ \\
\hline \multirow[t]{6}{*}{336} & D 61278 & $3.43 E-07$ & $4.75 E-07$ & $2.41 E-08$ & $7.20 \mathrm{E}-08$ \\
\hline & D49880 & $1.92 \mathrm{E}-05$ & $6.66 \mathrm{E}-06$ & $6.86 \mathrm{E}-07$ & $2.51 \mathrm{E}-07$ \\
\hline & D61245 & $1.5 \mathrm{E}-07$ & $1.07 \mathrm{E}-07$ & $7.39 \mathrm{E}-09$ & 1. $85 E-08$ \\
\hline & D 57522 & $9.39 E-08$ & 1. $12 \mathrm{E}-07$ & $6.38 E-09$ & $2.66 \mathrm{E}-09$ \\
\hline & D38989 & $1.53 E-05$ & $2.36 E-06$ & $2.93 E-07$ & $1.30 E-07$ \\
\hline & D 61747 & $1.57 \mathrm{E}-06$ & $7.70 E-07$ & $5.70 E-08$ & $5.50 E-08$ \\
\hline \multirow[t]{2}{*}{337} & D06339 & $8.64 \mathrm{E}-06$ & $5.83 E-06$ & $1.70 E-06$ & $1.09 \mathrm{E}-07$ \\
\hline & D56095 & $1.81 \mathrm{E}-04$ & $6.23 E-06$ & $2.70 \mathrm{E}-05$ & $1.91 E-06$ \\
\hline 339 & D35306 & 1. $28 \mathrm{E}-06$ & $4.22 E-07$ & $9.75 \mathrm{E}-08$ & $1.09 E-07$ \\
\hline \multirow[t]{4}{*}{341} & D 60056 & $8.58 \mathrm{E}-07$ & $6.42 E-07$ & $1.73 E-07$ & $9.39 E-08$ \\
\hline & D61504 & $2.14 E-06$ & $5.69 E-07$ & $1.56 \mathrm{E}-07$ & $6.29 E-08$ \\
\hline & D59053 & $2.39 E-05$ & $3.04 \mathrm{E}-06$ & $8.23 E-07$ & $4.07 \mathrm{E}-07$ \\
\hline & D47501 & $2.39 E-06$ & $2.54 \mathrm{E}-07$ & $7.61 \mathrm{E}-08$ & $2.97 E-08$ \\
\hline
\end{tabular}


mable range. This drum contained 4.757 percent hydrogen and 3.6 percent oxygen. Hydrogenoxygen mixtures containing greater than four percent hydrogen and greater than five percent oxygen are considered flammable. ${ }^{19}$ All of the IDC 336 drums sampled contained less than 100 grams of plutonium, but some of these drums contained between one and two percent hydrogen and from 1.5 to 10 percent oxygen. Calculations were performed using the lowest permeation rate shown in Table 10 for IDC 336 drums. These calculations show that if drums containing 100 to 500 grams of plutonium had been fitted with gaskets with the same low permeation rate, the drums would have contained from five to ten percent hydrogen. The residue drum backlog at Rocky Flats contains IDC 336 drums with plutonium contents as high as $\mathbf{4 8 4}$ grams. Therefore, if the combustible drums had not been fitted with vent filters, the residue drum backlog could have contained drums with high concentrations of hydrogen, and some of these drums might have contained flammable hydrogenoxygen mixtures.

Drum explosion tests conducted at the Savannah River Plant (SRP) showed that the pressure generated in a 55-gallon drum from a hydrogenoxygen reaction is dependent upon the hydrogen concentration. ${ }^{20}$ At hydrogen concentrations below 15 volume percent, only bulging of the drum lid and bottom occurred; the tests at SRP showed that visible bulging of the drum lid occurs at 1.5 psig. Hydrogen concentrations above 15 volume percent were required before the drum lid was blown from the drum. Therefore, an explosion in even the worst case IDC 336 drum would only have resulted in bulging of the drum lid and bottom.

When the study described in this report was started, the author was concerned about the possibility of hydrogen gas accumulating in the clam shells used to package certain types of residues. Calculations were performed that showed that clam shells could contain over 20 percent hydrogen if the loss of hydrogen is controlled by the rate of permeation of hydrogen through the clam shell wall. However, a study was conducted which demonstrated that hydrogen accumulation in clam shells should not be a problem. ${ }^{21}$ Study results showed that the leakage rate through the threads of clam shells is large enough to prevent hydrogen accumulation. These tests showed that the pressure in clam shells returns to atmospheric pressure within a few seconds, even when using initial pressures as high as $100 \mathrm{psig}$. These same tests showed that clam shell threads will not even hold water. Clam shells were filled with water through a hole in one end of the clam shell, and water began leaking through the threads as soon as the water level reached the top of the threads.

Gas generation problems are usually thought of as being confined to residues containing high concentrations of organic materials or liquids. However, the information in Table 1 indicates that gas generation problems could be associated with some of the pyrochemical salt residues. Some people interviewed indicated that pyrochemical salts are sometimes placed in plastic freezettes or two-liter plastic bottles before being removed from the glovebox. If pyrochemical salts with high plutonium and americium concentrations are stored in plastic containers, high hydrogen generation rates could result from radiolytic degradation of the plastic. A review of the residue drum database shows that most of the pyrochemical salts are stored in non-vented drums. If a non-vented drum contains high plutonium and americium content salts stored in plastic containers, then the possibility exists that the drum could be pressurized and could contain high hydrogen concentrations.

\section{Contamination Containment Loss}

Very little data exist on the incidence of contamination containment loss in residue drums. However, the incidence has been high enough in the past to lead to the installation of a Contamination Control Cell in Building 771 and down-draft rooms in Building 371. Installation of these 
contamination control facilities was prompted by past contamination incidents which occurred while opening residue drums during recovery operations. The drum residue backlog was packaged assuming short term storage (up to approximately two years) until the residue could be processed for plutonium recovery. The drum residue backlog is now destined to be stored for many years before the final disposition of the residue is determined. If problems with contamination containment loss have occurred in the past when the residue was being stored for shorter time periods, then incidents of contamination containment loss would be expected to increase during the long storage periods currently planned for the residue.

\section{Drum and Residue Packaging Corrosion}

A few incidents of documented drum corrosion problems have been discussed previously in this report (see Risk Factors: Drum and Residue Packaging Corrosion Section), but no well documented, systematic program has ever been put in place at Rocky Flats to determine the extent of drum corrosion problems. Corrosion of drum-lid vent filters has been observed on drums from several IDC categories. Corroded vent filters have been removed from drums of IDC $331,336,330$, and 338 residues. ${ }^{22}$ Most of the corroded vent filters have been removed from IDC 331 drums. Drum-vent filter corrosion can be observed by visual inspection of the exterior of the drum. Internal drum corrosion problems can be observed only by removing the drum lid and inspecting the interior surfaces of the drum. Probable drum corrosion mechanisms can be postulated based upon a knowledge of the chemical content of some of the residues in the backlog. However, the extent of the problem cannot be determined without a well documented, systematic drum inspection program. The possibility that pyrochemical salts stored in metal cans could be corroding the cans was discussed in the Risk Factors: Drum and Residue Packaging Corrosion Section. However, no documented incidents of metal can corrosion by pyrochemical salts could be found. Inspection of some of the stored pyrochemical salts is required to determine if this postulated corrosion of the metal cans is actually taking place.

\section{Reactive Metals and Compounds}

Possible mechanisms for reactions that could occur with reactive metals known to exist in some residues stored in the drum backlog have been described previously in this report (see Risk Factors: Reactive Metals and Compounds Section). However, no documented evidence could be found to determine the extent of the problem. Some of the potential hazardous compounds that could form in some of the residues could also react with other compounds, thus producing nonhazardous products. For example, sodium metal reacts with oxygen to form sodium peroxide. If sodium peroxide is brought into contact with sodium or plutonium metal, the resulting reaction can be violent. This reaction could initiate a hydrogen explosion in a drum containing an explosive mixture of hydrogen and oxygen. However, sodium peroxide reacts with water vapor to form sodium hydroxide and oxygen. Sodium peroxide also reacts with carbon dioxide to form sodium carbonate and oxygen. Therefore, even if sodium peroxide were present in some ER salts, the possibility exists that the peroxide has already reacted with water vapor or carbon dioxide. Some type of gas sampling and residue inspection and sampling program is required to determine if reactive metals contained in some residue categories pose a real safety problem.

Documented evidence was found for the formation of reactive compounds in at least one IDC category. In 1968, two incidents occurred which prompted a study of the flammability of leaded dry-box gloves. The first incident occurred at Rocky Flats in October 1968 when a minor fire occurred in a drum of used Hypalon-coated drybox gloves. ${ }^{12}$ No property damage or personnel injury resulted from the fire, but radioactive contamination was released from the drum into 
the surrounding room. The second incident occurred at Mound Laboratory when an explosion occurred in a muffle furnace being used to dry Hypalon-coated drybox gloves. ${ }^{23}$ This explosion was attributed to the ignition of flammable vapors emitted from the gloves during the drying operation. A study was conducted which showed that nitric acid attack on the leaded layer of drybox gloves results in the formation of a highly flammable material. ${ }^{12}$ This material was identified as lead nitrate in a matrix of unidentified organic material.

Tests conducted as part of the drybox glove study showed that exposure of leaded gloves to nitric acid solution or vapors resulted in attack on the leaded layer of the gloves. The product of this attack was a white or yellow material which was highly flammable when dried.

Thermogravimetric analyses and differential thermal analyses conducted on small samples of this material showed that the material burns in either air or argon atmospheres, with an ignition temperature of $260^{\circ} \mathrm{C}$. Other tests showed that the burning rate is very rapid, and the burning material cannot be extinguished with any of the dry-powder extinguishing agents in use at Rocky Flats at the time of the tests.

\section{A later study on the flammability of leaded} drybox gloves was conducted by exposing portions of leaded gloves to nitric acid solutions ranging in concentration from 7 to $15.7 \mathrm{~N}^{13}$ Some of the glove material was abraded prior to exposure to nitric acid, but some undamaged glove material was also exposed to nitric acid. In both cases, attack on the leaded layer by nitric acid resulted in the formation of yellowish granules which were identified as a mixture of carboxylic acids containing randomly substituted nitro groups and lead nitrate. Ignition tests conducted on this material resulted in ignition temperatures as low as $60^{\circ} \mathrm{C}$. These ignition tests revealed that in the range of 0.2 to one gram of material, the ignition temperature decreases as the quantity of material increases. Other tests showed that the material could be ignited with sparks from a welding-torch igniter, and that the material is shock sensitive. Using a standard drop-weight shock sensitivity test, an impact energy of between 50 and $75 \mathrm{~kg}-\mathrm{cm}$ was found to result in explosive decomposition of the material.

This later study also revealed that the flammable material formed from the reaction of nitric acid with drybox gloves could be removed by washing the nitrated glove material in hot water. A glove washing operation was installed in the Size Reduction Vault (SRV) in Building 776 during 1977-78. ${ }^{24}$ This washing operation used a round drum that could be turned to tumble the gloves in a water solution. This operation was shut down in 1988 , but the glove washing equipment is still in place in the SRV.

A gas sampling and drum venting project conducted on 19 drums of combustible material in the fall of 1993 was described previously in this report. The gas samples obtained from four drums containing acid-contaminated drybox gloves (IDC 341) were also analyzed for NOx. The results from these gas samples showed that three of the four IDC 341 drums contained elevated concentrations of NOx (from 0.147 to 1.399 volume \%). The elevated NOx concentrations indicate that these drums contain nitric acid, which could be reacting with the leaded layer of the gloves stored in these drums to form the flammable, shock-sensitive material. Gas sampling project results showed that venting these IDC 341 drums is necessary to prevent a buildup of flammable hydrogen-oxygen mixtures. However, venting of the drums accelerates drying of the gloves.

A number of potential safety problems that could exist in the residue drum backlog have been identified in this report. However, very little data exists that can be used to verify the existence of the potential safety problems or to determine the severity of the safety risks. A number of steps have been proposed to obtain the data required to quantify the extent of the 
safety problems that exist in the residue drum backlog. These steps include (1) drum head space gas sampling studies, (2) drum and residue inspection programs, and (3) residue sampling studies. These recommended studies will be costly, but a better definition of the safety problems actually existing in the residue drum backlog would allow steps to be taken to address the safety risks before a real problem occurs.

\section{CONCLUSIONS AND RECOMMENDATIONS}

An evaluation of the types of risks associated with the residue categories currently stored in the residue drum backlog reveals that the potential for safety problems with the drums stored in the backlog does exist. Based on the data currently available, no imminent safety hazards have been identified. However, the potential safety risks appear to be sufficiently real to warrant further investigation. The potential safety risks identified during the study described in this report include (1) residue drums pressurization, (2) hydrogen accumulation in residue drums, (3) contamination containment loss, (4) drum and drum-vent filter assembly corrosion, (5) metal residue container corrosion, and (6) pyrophoric or unstable compound formation in drums containing plutonium or reactive metals. All the information required to determine the extent of the hazard posed by these safety risks is not currently available. Recommendations for actions to obtain the required information are given below.

1. Expand the WEMS database to include infor mation on the condition of the backlog residue drums, and provide a central location for collection of information on the residue drums' current condition.

2. Inspect all residue drums not fitted with drum vent filter assemblies to determine if any of these drums are pressurized.

3. Conduct visual inspections of drums in IDC categories $330,331,336,337,338,339$ and
341 to check for vent filter corrosion. IDC 331 drums should be inspected every six months, and drums in the other IDC categories should be inspected every year.

4. Expand the drum head space gas sampling program that was started with the resin and combustible residue drums to include drums from other residue categories. Inspection of the residue drums for corrosion, inspection of the residue packaging integrity, and verification of residue packaging configurations should be accomplished as part of the gas sampling program.

5. Develop a program to determine if the formation of pyrophoric and unstable compounds in drums containing plutonium or reactive metals is actually occurring. This program should include inspection of the metal cans used to store pyrochemical salt residues to determine if metal can corrosion is occurring.

\section{REFERENCES}

1. A. R. Kazanjian, et al, Gas Generation Results and Venting Study for Transuranic Waste Drums, RFP-3739, Rockwell International, Rocky Flats Plant, Golden, CO. September 23, 1985.

2. A. R. Kazanjian, Radiolytic Gas Generation in Plutonium Contaminated Waste Materials, RFP-2469, Rockwell International, Rocky Flats Plant, Golden, CO. October 29, 1976.

3. A. R. Kazanjian and D. R. Horrell, Thermal and Radiation Stability of Polyvinyl Chloride, RFP-1924, Dow Chemical Co., Rocky Flats Plant, Golden, CO, September 1, 1972.

4. D. A. Hoover and W. P. Ingalls, Study of Polyethylene Bottles as Containers for Plutonium Nitrate, ARH-SA-18, Atlantic Richfield Hanford Company, Richland, WA, June 1968. 
5. T. R. Hergert and L. G. Peppers, EG\&G Rocky Flats, Inc., Rocky Flats Plant, Golden, Colorado, unpublished data, June 22, 1993.

6. L. G. Peppers and T. R. Hergert, EG\&G Rocky Flats, Inc., Rocky Flats Plant, Golden, Colorado, unpublished data, October 15, 1992.

7. S. W. Kranker, EG\&G Rocky Flats, Inc., Rocky Flats Plant, Golden, Colorado, personal communications, November 5, 1993.

8. W. V. Conner, Process Studies on the Reduction of Plutonium Tetrafluoride to Metal, RFP-728, Dow Chemical Co., Rocky Flats Plant, Golden, CO, May 11, 1966.

9. J. M. Cleveland, The Chemistry of Plutonium, p. 375, American Nuclear Society, 1979.

10. J. M. Haschke, et al, The Reaction of Plutonium With Water. Kinetic and Equilibrium Behavior of Binary and Ternary Phases in the $\mathrm{Pu}+\mathrm{O}+\mathrm{H}$ System, US DOE Report, RFP3416, Rockwell International, Rocky Flats Plant, Golden, CO, February 1983.

11. F. A. Cotton and G. Wilkinson, Advanced Inorganic Chemistry, 4th Ed, 1980, New York, John Wiley \& Sons, pp 497-499.

12. T. C. Johnson and J. W. Lindsay, Flammability of Lead Dry Box Gloves, RFP-1354, Rocky Flats Plant, The Dow Chemical Company, Golden, Colorado, June 9, 1969.

13. J. L. Long and C. J. Smith, Unstable Material Formed by Reacting Leaded Rubber Gloves With Nitric Acid, RFP-2648, Rocky Flats Plant, Rockwell International, Golden, Colorado, November 4, 1977.

14. S. H. Davies, EG\&G Rocky Flats, Inc., Rocky Flats Plant, Golden, Colorado, personal communications, Rocky Flats Plant, August 18, 1993.
15. T. L. Clements and D. E. Kudera, TRU Waste Sampling Program: Volume I-Waste Characterization, EGG-WM-6503, EG\&G Idaho, Inc., Idaho Falls, Idaho, September 1985.

16. T. L. Clements and D. E. Kudera, TRU Waste Sampling Program: Volume II-Gas Generation Studies, EGG-WM-6503, EG\&G Idaho, Inc., Idaho Falls, Idaho, September 1985.

17. J. A. Oleary, EG\&G Rocky Flats, Inc., Rocky Flats Plant, Golden, Colorado, unpublished data, February 9, 1994.

18. R. Saiki and T. L. Mcfetters, EG\&G Rocky Flats, Inc., Rocky Flats Plant, Golden, Colorado, unpublished data, Rocky Flats Plant, September 9, 1988.

19. H. F. Coward and G. W. Jones, Limits of Flammability of Gases and Vapors, Bulletin 503, Bureau of Mines, U.S. Government Printing Office, Washington, D. C., 1952.

20. K. L. Dykes and M. L. Meyer, TRU Drum Hydrogen Explosion Tests, WSRC-TR-90165, Westinghouse Savannah River Co., Aiken, South Carolina, June 1991.

21. T. R. Hergert and T. L. Mcfetters, EG\&G Rocky Flats, Inc., Rocky Flats Plant, Golden, Colorado, unpublished data, Rocky Flats Plant, March 16, 1994.

22. L. G. Peppers, EG\&G Rocky Flats, Inc., Rocky Flats Plant, Golden, Colorado, personal communications, September 2, 1993.

23. Serious Accidents USAEC Issue No. 293, August 26, 1968.

24. E. Johnson, EG\&G Rocky Flats, Inc., Rocky Flats Plant, Golden, Colorado, personal communications, February 16, 1994. 